\title{
Revising Social Contracts: Social Spending in Latin America, East Asia, and the Former Socialist Countries, 1980-2000*
}

\author{
Stephan HagGard \\ University of California, San Diego \\ ROBERT KaUFMAN \\ RUTGERS UNIVERSITY
}

Resumen

Este trabajo examina los determinantes del gasto social en América Latina, Europa Oriental y el Este Asiático durante los años 80 y los 90 . Presumimos que las diferencias duraderas y significativas en las herencias del estado de bienestar y las restricciones fiscales afectaron la manera en la cual los países en las tres regiones respondieron a los desafíos de las crisis económicas más contemporáneos, la integración en los mercados globales y las transiciones a la democracia. Los paises latinoamericanos, que heredaron las restricciones fiscales más severas, fueron los que menos pudieron proteger el gasto social durante momentos de apremio económico. Los países del Este Asiático, y en un grado menor, los de Europa Oriental, fueron menos proclives a reducir el gasto social en vistas a los apremios económicos e inclusive se vieron más inclinados a aumentarlo durante las transiciones democráticas.

\begin{abstract}
This paper examines the determinants of social spending in Latin America, Eastern Europe, and East Asia during the 1980s and 1990s. We hypothesize that pronounced and enduring differences in welfare legacies and fiscal constraints affected the way countries of the three regions responded to more contemporary challenges of economic crisis, integration into global markets, and transitions from autocracy to democratic rule. Latin American countries, which inherited the most severe fiscal constraints, were least able to protect social spending during economic downturns. East Asian countries and, to a lesser extent, those of Eastern Europe, were less likely to reduce social spending in the face of downturns and somewhat more likely to increase during democratic transitions.
\end{abstract}

\section{PALABRAS CLAVE • Social Spending • Latin America • Eastern Europe • Asia}

\footnotetext{
Originally prepared for presentation at the annual convention of the International Studies Association, Montreal, March 17-20, 2004. Revised for presentation at the Workshop on East European Politics, Center for European Studies, Harvard University, May 6, 2004. We would like to thank Barak Hoffman and Jing Chen for research assistance and George Avelino, David Brown, William C. Clark, Tim Frye, Wendy Hunter, Maria Victoria Murillo, Jon Rodden, Peter Rosendorff, Alex Segura-Ubiergo, Jeff Timmons, Florencia Torche and Eric Wibbels for assistance and comments on earlier drafts. This paper is part of a larger project entitled Recrafting Social Contracts: Welfare Reform in Latin America, East Asia and Central Europe.
} 
The 1980s and 1990s were turbulent decades for the middle-income countries of Latin America, Eastern Europe and the former Soviet Union. In both regions, severe financial or "transitional" economic crises forced fundamental reforms in existing development models, including privatization, deregulation of markets and substantial external liberalization and increased economic openness. By contrast, economic growth in East Asia remained robust through the mid-1990s. But many countries in that region succumbed to a financial crisis in the late-1990s that also called into question previous approaches to economic growth, for example, with respect to corporate governance and the operation of financial markets.

These economic and policy changes took place in a very different political environment, and in some cases precipitated regime change. Virtually all countries in the three regions underwent processes of political liberalization during the 1980s and 1990s, and most became fully democratic even if the quality of democracy and the extent of its "consolidation" remain in dispute.

This paper examines the political economy of social policy in these three regions over the last two decades. More specifically, we examine the determinants of social spending, including the effects of increasing integration into international markets and transitions from autocracy to democratic rule. However, a central theoretical and empirical theme is the legacy of past policies, and the extent to which prior commitments affected the course of social policy reform during the current period.

Changes in the delivery of social insurance and services typically involve complex institutional reforms, such as the privatization of pensions or the decentralization of the education and health sectors; in other components of this project we consider these reforms in more detail. Here, we begin our analysis by looking at the determinants of government spending. Following the literature on the advanced industrial states, we consider both aggregate government expenditures - a gauge of the size of the public economy-and three categories of social spending for which there is reasonably good data for a panel of countries: education, health, and social security.

A focus on social spending has a number of shortcomings that must be acknowledged from the outset. First, understanding the social implications of broad spending categories requires more fine-grained analysis of how spending is actually directed (Esping-Anderson, 1990; Kapstein and Milanovic, 2003; Burgoon, 2003). Second, governments have other means for achieving social objectives beyond spending. A decline in social spending might reflect organizational changes that improve efficiency and reduce costs. Alternatively, such declines may reflect a shift towards instruments that encourage individuals to manage risk and acquire services on their own, such as mandated savings programs or tax incentives (Gilbert, 2002). Third, we recognize that it is also important to look beyond spending to real social outcomes, such as infant mortality, literacy, or life expectancy (see for example, Frey and Al-Roumi, 1999; Baum and Lake, 2001, and the work of McGuire on infant mortality, McGuire, 2001). This last step is particularly important because of the ongoing debate about whether spending has its intended social effect (see for example Rajkumar and Swaroop, 2002).

Despite these reservations, the allocation of public resources to social security, health, and education constitutes one important measure of public effort, and it is useful to map the way spending has evolved in recent decades and the nature of the economic and political forces that have affected it. Spending is also important for our purposes because of the profound fiscal constraints faced by many developing and transitional economies during the 1980s and 1990s. A central theoretical 
point that we seek to explore, and one we believe has been largely neglected (see however, Kato, 2002; Lindert, 2004), is the role that revenue plays as a determinant of spending. Governments with a weak revenue base and expansive public commitments were more likely to face fiscal and financial constraints on social spending, even in the face of pressure from beneficiaries and other stakeholders to maintain it.

Our discussion proceeds in four steps. We begin in Section I with some theoretical considerations, focusing particular attention on historical legacies of prior welfare systems. We then turn to a descriptive overview of government spending in Latin America, Asia and Central Europe between 1980 and 2000, which suggests strongly the path dependent nature of social spending. In Section III we use a cross-section design to get at some of the long-run structural factors that influence government spending: per capita income, revenue, economic openness and democracy. In Section IV we report the results of pooled time series models testing similar hypotheses, but designed to capture the dynamics of social spending during the last two decades.

\section{THEORETICAL CONSIDERATIONS: THE POLITICAL ECONOMY OF WELFARE SPENDING IN DEVELOPING AND TRANSITIONAL ECONOMIES}

Our analysis of social spending during the 1980s and 1990s is framed by pronounced and persistent differences in the welfare systems of these three regions. In other parts of this project, we argue that these differences derive from two sources: distinctive critical junctures that shaped the formation of national states and their relation to organized labor; and development strategies, namely importsubstitution in Latin America, export-led growth in East Asia, and state socialism in Eastern Europe. Although our argument about the origins and evolution of regional welfare systems requires a much more extensive elaboration than we can present here, the principle components can be summarized as follows.

In East Asia and Eastern Europe, contemporary states were established at the end of World War II through decolonization and Soviet occupation respectively. In both regions, the form taken by these states was shaped decisively by Cold War rivalries and great power influence, if not outright domination, of the respective regions. A common feature of both sets of countries - despite fundamental differences in other respects - was the nearly total repression of unions as independent political actors and the subordination of labor to the larger political and developmental goals of the state. This fact facilitated the pursuit of distinctive development models, one operating under the permissive umbrella of alignment with the United States, the other imposed by the Soviet Union.

In East Asia, the control and repression of organized labor facilitated not only the elaboration of an export-oriented development model, but also an extremely narrow range of public social security commitments. Social insurance - pensions, health and unemployment - was minimal except for workers in the public sector and a highly restricted set of large private sector enterprises. Outside of basic public health services, health systems were dominated by private financing and provision to a much greater extent than in Latin America or Eastern Europe, creating an important space for private actors to flourish. The implicit social contract for low-income groups rested on access to education, expanding opportunities for employment, upward mobility into the middle class, and the accumulation of private savings that could provide the basis for self-insurance and inter-familial transfers. 
The command economy constructed by communist elites in Eastern Europe also presupposed both the destruction of independent labor organizations, as well as the replacement of labor markets by bureaucratic manpower planning. The coordination and reproduction of the labor force rested on explicit or implicit employment guarantees and the extension of many services, including health and housing, on a universal, if necessarily rationed and low-quality, basis. All service providers were, of course, employed in the state sector. Education systems were highly egalitarian at the primary and secondary level, but were closely linked to the manpower planning process and thus severely limited personal choice.

In Latin America, the critical juncture associated with the reform of oligarchic states occurred at earlier periods in the twentieth century and was much less constrained by the great power rivalries of the Cold War era. In contrast to East Asia and Central Europe, the reform coalitions that displaced oligarchic states rested on a partial incorporation or cooptation of labor organizations that generally retained a degree of independence and influence as political actors. These arrangements were reinforced both by a move toward import-substitution industrialization (ISI), and by the extension of protections to the labor clientele. Social insurance systems were built around employment in government, state-owned enterprises, and in the formal private sector, where unions were strongest. Employment in these sectors provided the principal basis for entitlements in pay-as-you-go social insurance systems that included not only old-age pensions, but health coverage and family allowances as well. Comprehensive labor legislation governing hiring and dismissal was a crucial political component of the incorporation of labor, and provided a form of employment security even in the absence of formal unemployment insurance. In the absence of either ideological imperatives or a demand for skilled labor, education was not given the same priority it received in other regions; Latin America remains "undereducated" for its level of development.

Figure 1 presents a stylized portrait of some important differences in policy emphasis and fiscal commitment to social spending that had evolved in these regions by the late 1970s and 1980s. Eastern European countries developed full-fledged welfare states, albeit often with low quality services and either rationing or under-the-table private provision of care. A number of the highgrowth Asian countries offered very spare public commitments to social insurance, or mandated it only through private savings in a provident fund model. However, they demonstrated early and strong commitment to the expansion of educational opportunity (albeit much less to health). Finally, many of the Latin American countries developed quite extensive forms of social insurance, particularly pensions and linked health insurance systems, but typically targeted on relatively narrow constituencies. Commitment to provision of basic health and particularly education lagged substantially behind other countries at comparable levels of development. 
FIGURE 1: Components of Regional Welfare Systems

\begin{tabular}{|c|c|c|c|}
\hline & Latin America & East Asia & Eastern Europe \\
\hline Fiscal commitments & Extensive & Limited & Extensive \\
\hline Priorities & $\begin{array}{l}\text { Extensive social } \\
\text { insurance; more } \\
\text { limited attention to } \\
\text { health and education }\end{array}$ & $\begin{array}{l}\text { Minimal social } \\
\text { protection. High } \\
\text { emphasis on the } \\
\text { development of } \\
\text { human capital, } \\
\text { particularly through } \\
\text { education }\end{array}$ & $\begin{array}{l}\text { Comprehensive } \\
\text { guarantees of } \\
\text { employment, } \\
\text { education and } \\
\text { health provision }\end{array}$ \\
\hline Coverage & $\begin{array}{l}\text { Social insurance and } \\
\text { education directed } \\
\text { toward formal sector } \\
\text { workers, government } \\
\text { employees, and } \\
\text { middle class }\end{array}$ & $\begin{array}{l}\text { Public social } \\
\text { insurance limited to } \\
\text { very narrow groups. } \\
\text { Comprehensive } \\
\text { coverage on primary } \\
\text { education. }\end{array}$ & $\begin{array}{l}\text { Universal coverage } \\
\text { in both social } \\
\text { protections and } \\
\text { entitlements to } \\
\text { health and education } \\
\text { services. }\end{array}$ \\
\hline $\begin{array}{l}\text { Strength of Service } \\
\text { Providers }\end{array}$ & $\begin{array}{l}\text { Strong teachers and } \\
\text { health unions. } \\
\text { Politically-powerful } \\
\text { social security esta- } \\
\text { blishment }\end{array}$ & $\begin{array}{l}\text { Generally weak, } \\
\text { although growth } \\
\text { over time in the } \\
\text { weight of private } \\
\text { providers }\end{array}$ & $\begin{array}{l}\text { Providers lack for- } \\
\text { mal political } \\
\text { independence but } \\
\text { constitute a large } \\
\text { bloc of public sector } \\
\text { workers }\end{array}$ \\
\hline
\end{tabular}

These different welfare models are consequential because we expect there to be a relationship between the fiscal position of the government and the political economy of welfare reform. Where there is a legacy of substantial fiscal commitments, and where governments face fiscal constraints, they face significant economic risks if they attempt to undertake new spending commitments or to engage in counter-cyclical policy. On the other hand, attempts to scale back spending pose significant political risks given a widespread sense of entitlement and strong, well-organized stakeholders.

It follows that the pressures on social spending and the politics of social policy can be expected to vary by region. In Latin America, where high fiscal commitments were accompanied by a relatively limited tax capacity, the costs of ignoring fiscal constraints were high. On the other hand, benefits were distributed very unequally, and large sectors of the population, particularly in the rural and urban informal sectors, were excluded from coverage entirely. Thus, although stakeholders were powerful, cutbacks did not necessarily generate a broadly-based political backlash. In East Asia, limited coverage created political incentives for expansion of benefits to uncovered segments of the population, particularly given the transition to democratic rule. The absence of significant fiscal constraints provided the permissive conditions for doing so. In East Central Europe, despite a relatively large revenue base inherited from the command economies of the communist era, governments faced 
major fiscal pressures in sustaining large welfare commitments. On the other hand, rolling back entitlements that covered large sectors of the population also entailed significant political costs.

To the extent such legacies constrain government choices, we can also expect that we will see cross-regional differences in the effects of democratization and integration into global markets. Since arguments regarding these factors have been widely discussed, the principal expectations about them need only be briefly summarized here. Among the relatively well-institutionalized democracies of the $O E C D$, the balance of partisan power has been assigned a prominent causal role in the development of the welfare state. Among developing countries, however, regime type is itself a variable. Ceteris paribus, we would expect democracy to generate more social spending as politicians respond to the incentives of electoral competition and the activation of previously excluded social interests (Brown and Hunter, 1999).

Expectations about the effects of globalization are more mixed, as Garrett (1998) has noted. A "compensation" hypothesis, first articulated by Cameron (1978) and later by Katzenstein (1985), argues that greater openness is associated with greater volatility and risk and thus increased demands on the public sector for social insurance and services. A number of studies, most notably by Rodrik (1997, 1998, 1999) and Garrett (2000, 2001, Garrett and Mitchell, 2001; Garrett and Nickerson, 2001) have found a positive relationship between openness and government spending. On the other hand, an alternative argument suggests that increasing economic integration is likely to constrain government spending: as a consequence of competitive pressures on the tax base, and on payroll taxes in particular; and through the weakening of political forces such as labor that typically advocated and defended social policy commitments (see Garrett, 1998; Boix, 1998; Grunberg, 1998; Swank, 1998; Garrett and Mitchell, 2001).

Arguments about the effects of democratization and globalization have typically been explored either with respect to global samples (Rudra, 2002), or in samples of countries in one geographic region (Brown and Hunter, 1999; Kaufman and Segura-Ubiergo, 2001; Lipsmeyer, 2002; Frye, 2003). Our theoretical hunch is that the effects of both democratization and globalization will depend in part on the fiscal commitments and expectations surrounding the welfare legacies. In Asia, where governments inherited looser fiscal constraints, states had more options with respect to the expansion of public insurance and services, as they became more democratic and more integrated into international markets. In the more fiscally constrained regions - Latin America and Eastern Europe- even democratic states found themselves in a weaker position to respond to pressures for expansion, and might well be forced to cut back expenditures in response to globalization.

Our emphasis on the potential importance of fiscal legacies within the three regions is relevant to current debates over the extent to which "path dependence" has shaped responses to welfare challenges in both the developed and developing world (Pierson, 2000; Mahoney and Reuschmeyer, 2003). "Strong" path dependent arguments rest on the proposition that the costs of switching from a given path are prohibitive and that change thus occurs, if at all, within very narrow bounds (see Pierson, 1994).

In their strong form, such arguments do not appear well suited to contemporary developments within the countries of interest to us; in each region, the economic and political transformations of recent decades can be considered "critical junctures" that reduce the costs and increase the 
payoffs of switching to a new path (Pierson: 263; Collier and Collier, 1991). Nevertheless, to the extent that welfare legacies constrain these choices, a weaker version of the path dependency perspective may be relevant in two ways. First, such arguments recognize the existence of increasing returns associated with a particular path, but treat switching costs as a variable that is also subject to contemporaneous influences. Beneficiaries of entitlements, for example, may constitute an important status-quo group, but their relevant influence may depend on intervening variables such as the degree of organization or their capacity to forge alliances with other powerful interests.

Path dependence is also relevant because prior development models and social policy choices define the issue space and therefore the reform agenda. As we have discussed above, social contracts in the three regions involve different levels of coverage, different priorities attached to social protection and human capital, and different balances between the public and private sphere. As a component of these models, we that current spending commitments will be constrained by the spending commitments and tax capacity developed in previous decades.

\section{SOCIAL SPENDING IN LATIN AMERICA, EAST ASIA AND CENTRAL EUROPE, 1980-2000}

Our first step in exploring these issues is to examine the way social spending has actually evolved in recent decades. Figures 2 - 4 trace social security, health, and education spending as a share of GDP for the three regions. Throughout, we consider the period from 1980 through 2000 for Latin America and East Asia, and the transitional decade of the 1990s for Eastern Europe and the former Soviet Union. The data offer strong evidence of continuity with earlier periods. With respect to the weight given to different spending categories, we see the sharpest differences in social security and health spending. Eastern Europe and the former Soviet Union inherited very large commitments in these policy areas, and maintained them to some extent even following the great transformation that began in 1989-90. Latin America spent substantially more on social security and health as a share of GDP than the East Asian countries, which continued to show minimal public commitment to social security in particular. With respect to education, by contrast, the emphases are virtually reversed. East Asia spent more as a share of GDP than either Eastern Europe or Latin America in the earlier period, and continued to do so during the period under consideration here. 
FIGURE 2: Social Security Spending in Latin America, East Asia, Eastern Europe and the Former Soviet Union, 1980-2000 (percent of GDP)

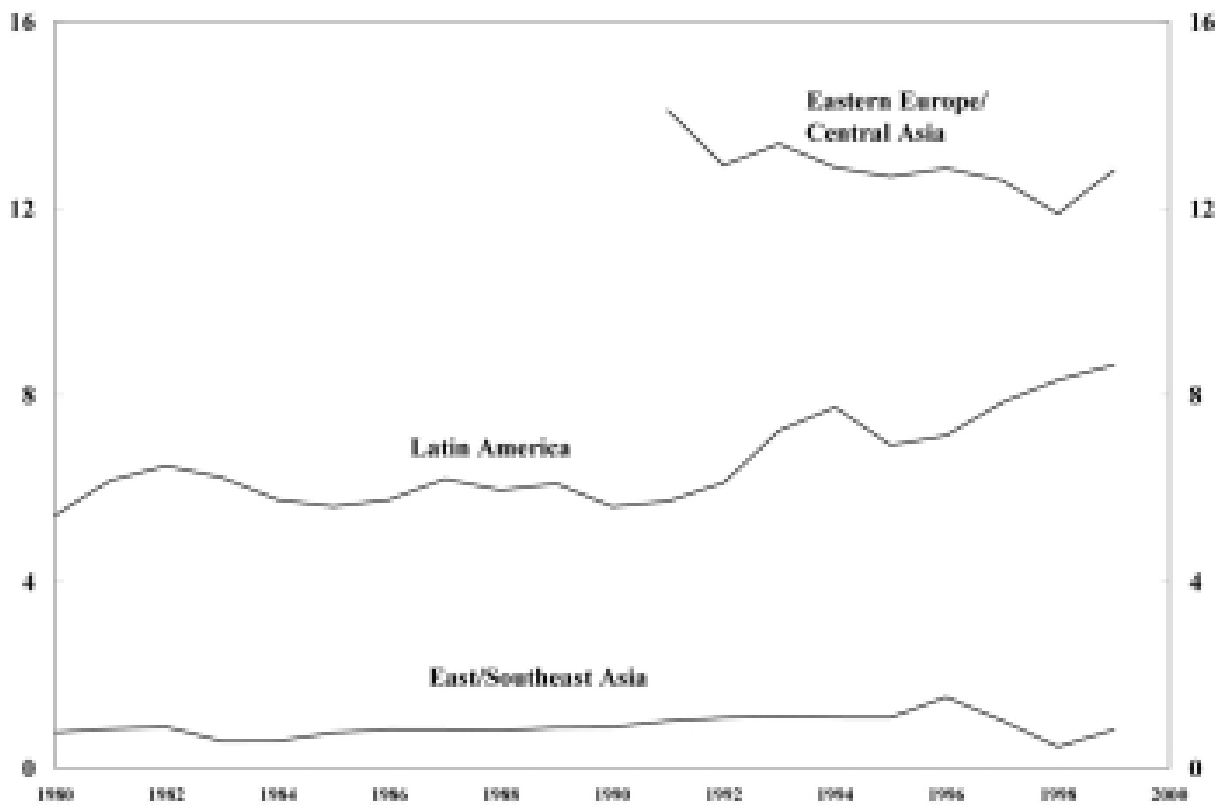

Sources: IMF's Government Financial Statistics, World Bank's World Development Indicators, and from the GFS.

FIGURE 3: Education Spending in Latin America, East Asia, Eastern Europe and the Former Soviet Union, 1980-2000 (percent of GDP)

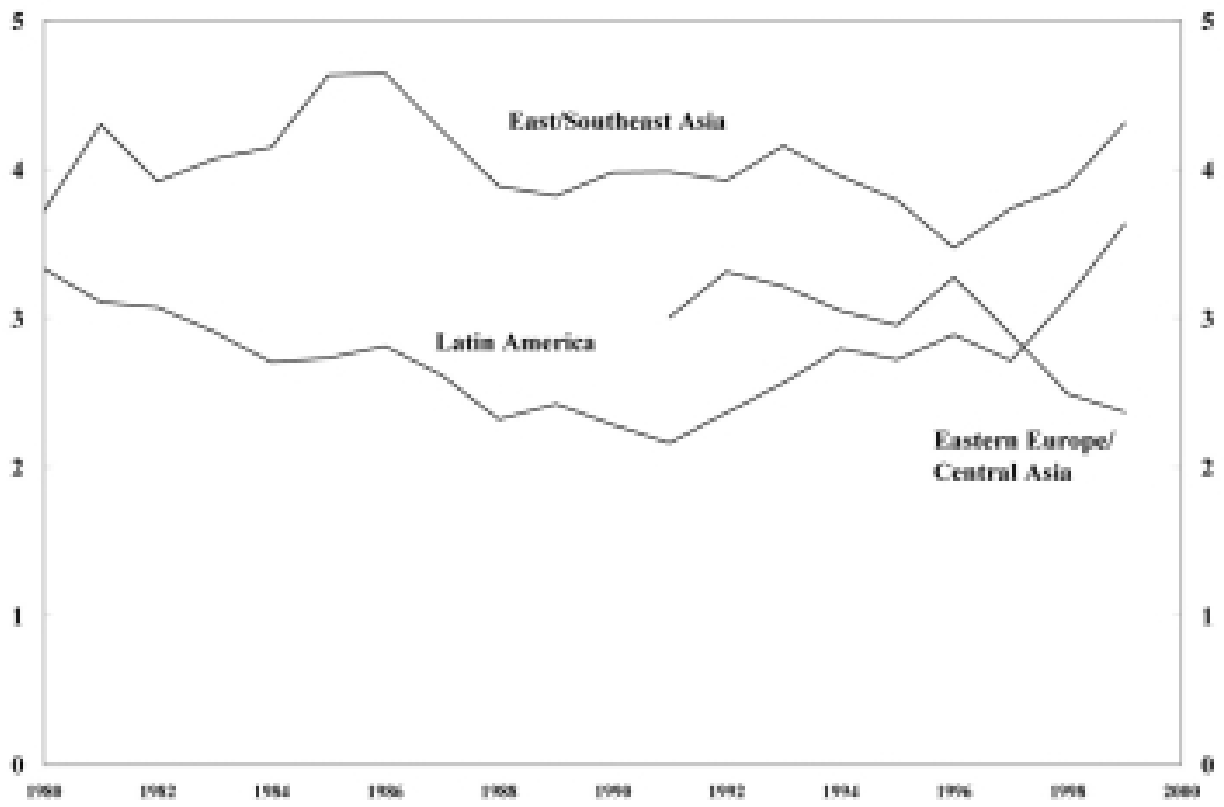

Sources: IMF's Government Financial Statistics, World Bank's World Development Indicators, and from the GFS. 
FIGURE 4: Health Spending in Latin America, East Asia, Eastern Europe and the Former Soviet Union, 1980-2000 (percent of GDP)

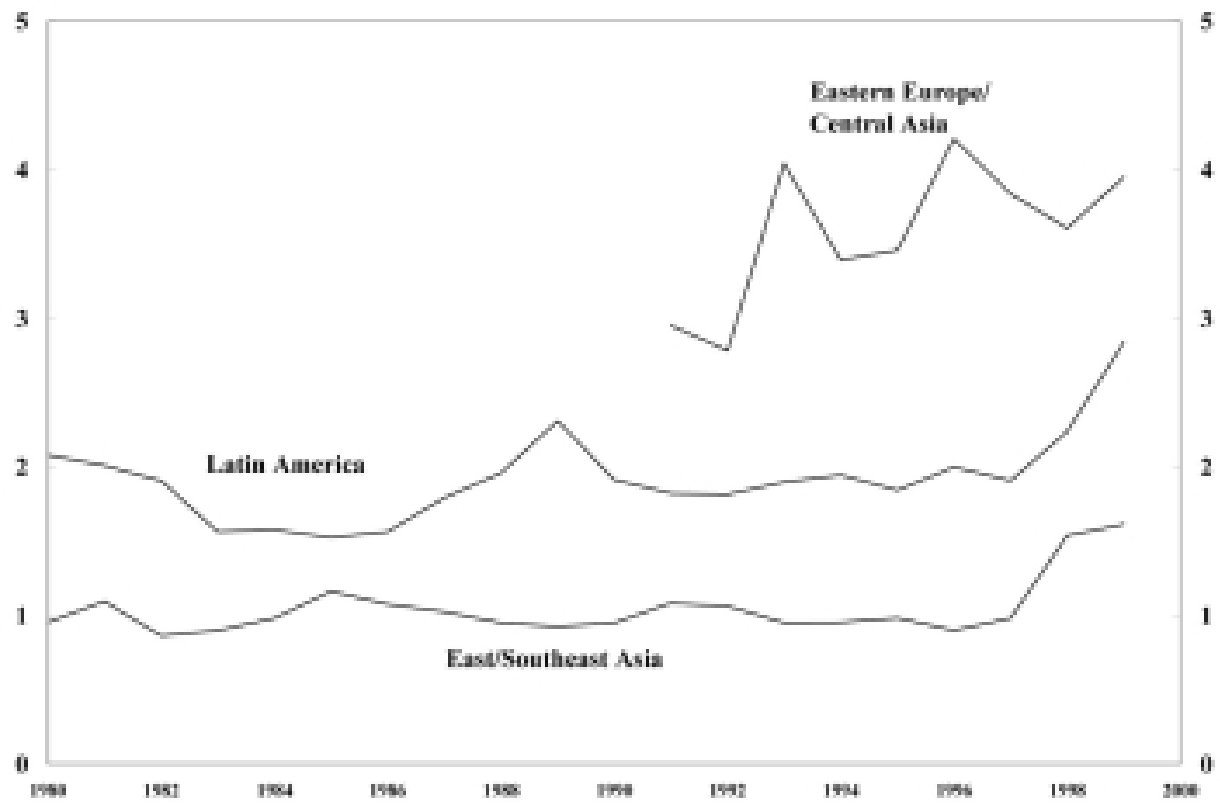

Sources: IMF's Government Financial Statistics, World Bank's World Development Indicators, and from the GFS.

Table 1 summarizes average annual changes in expenditure and revenues, both as a share of GDP and in per capita terms. The data calls into question at least one form of the argument that the period of increased globalization has been associated with a decline in social spending in developing and transitional economies. Despite the cross-regional differences noted above, all three regions saw a reallocation of spending toward health, education, and social security during the period. This can be seen from the fact that the growth in social spending either outpaced growth in aggregate expenditure (Asia), or declined less rapidly (Latin America and Eastern Europe). In all three regions, moreover, changes in social spending showed much less volatility than did the levels of aggregate government spending, consumption or revenue, suggesting that governments either protected or smoothed such spending or were constrained from cutting it (for example, because of entitlements).

The priorities of the three regions also differed in discernible ways. In Latin America, central government health and social spending grew at a more rapid rate than education spending, although this difference is probably explained in part by the move across the region to decentralize education. In East Asia, health and social security spending, long ignored by governments, witnessed relatively robust growth. In Eastern Europe, health spending continued to grow, but both social security and education spending fell.

The per capita spending data shown in Table 1 provide a quite different perspective on these trends, however, and a more skeptical view of social spending during this period of increased globalization. The large differences in overall growth rates across the three regions had profound consequences for real per capita spending growth. In the dynamic economies of East Asia, spending remained relatively flat as a share of GDP, but real per capita social spending increased rapidly. In 
Latin America, much more modest growth rates implied that substantial shifts in per capita social spending were unlikely to occur in the context of constant spending shares. Such increases could only be achieved by the more politically difficult task of reallocating resources in the budget, ie., by increasing spending shares. In Eastern Europe and the former Soviet Union, the collapse in spending is even more marked when measured on a per capita basis.

In the following sections of this chapter, we focus on spending as a share of GDP, and control for the effects of income and growth by using GDP per capita and GDP growth as control variables in our cross-sectional and time-series models respectively. Nevertheless, it is important to bear in mind the implications of macroeconomic developments during the 1980s and 1990s in the three regions. As we will show, the most striking feature of the economic landscape in Latin America and Eastern Europe was the profound crises the two regions experienced in the 1980s and 1990s and the pressures these crises placed on existing development models.

Economic crises had contradictory implications for social policy. On the one hand, we would expect widespread social distress to be associated with increased demand for the provision of social safety nets. On the other hand, slow growth intensifies constraints on revenues and has implications for the ability of governments to increase, or even protect, social spending. In contrast to countries experiencing high growth, as in East Asia prior to the financial crisis, slow growth implies lower per capita expenditure growth unless there is a reallocation of spending. As a consequence, we might expect distributive conflicts over social spending to be more intense in Latin America and Eastern Europe. 
TABLE 1: Revenue and Spending Growth, 1980-2000

Average Growth of Revenue and Spending as a Share of GDP

\begin{tabular}{lccc} 
& Latin America & East Asia & $\begin{array}{c}\text { Eastern Europe } \\
(1990-2000)\end{array}$ \\
\hline Revenue & 0,38 & $-0,02$ & $-2,79$ \\
Expenditure & 0,73 & 0,05 & $-2,12$ \\
Consumption & 0,66 & $-0,4$ & $-0,59$ \\
Education & 0,76 & 1,03 & $-2,57$ \\
Health & 2,27 & 3,86 & 5,24 \\
Social Security & 2,75 & 4,4 & $-1,07$ \\
\hline
\end{tabular}

\section{Average Growth in Per Capita Revenue and Expenditure}

\begin{tabular}{lccc} 
& Latin America & East Asia & Eastern Europe \\
\hline Revenue & 1,21 & 3,94 & $-4,35$ \\
Expenditure & 1,57 & 4,02 & $-3,69$ \\
Consumption & 1,49 & 3,55 & $-2,19$ \\
Education & 1,6 & 5,03 & $-4,14$ \\
Health & 3,12 & 7,97 & 3,54 \\
Social Security & 3,6 & 8,54 & $-2,65$ \\
\hline Memo: & & & \\
Average GDP Growth & 2,64 & 6,03 & $-1,07$ \\
Average Per Capita GDP Growth & 0,83 & 3,96 & $-1,43$ \\
\hline
\end{tabular}

\section{Standard Deviation of Revenue and Expenditure}

\begin{tabular}{lccc} 
& Latin America & East Asia & Eastern Europe \\
\hline Revenue & 5,75 & 5,01 & 9,40 \\
Expenditure & 6,09 & 5,15 & 9,35 \\
Consumption & 3,72 & 2,17 & 4,98 \\
Education & 1,36 & 1,33 & 1,22 \\
Health & 1,75 & 0,52 & 2,17 \\
Social Security & 4,30 & 0,49 & 3,86 \\
\hline
\end{tabular}

Sources: IMF's Government Financial Statistics, World Bank's World Development Indicators, and from the GFS. 


\section{THE STRUCTURE OF SOCIAL SPENDING IN DEVELOPING AND FORMERLY SOCIALIST COUNTRIES: A CROSS-SECTIONAL ANALYSIS}

What accounts for these cross-regional differences in government spending on social insurance and services in recent decades? In this section, we examine the way long-term fiscal performance in the countries of our three regions compare with overall patterns within a global sample of middle-income countries. We look first at the determinants of revenue. We then examine the way revenues and a variety of other control variables influence differences in spending. These results are reported in Tables 2 and 3. We use dummies to ascertain the effects of regional factors within these general models, and an analysis of residuals to ascertain the extent to which specific countries spent more or taxed less than levels predicted in the models.

Ceteris paribus, social spending should vary directly with the revenue base. Governments with a weak revenue base are more likely to face fiscal and financial constraints on social spending, even in the face of pressure from beneficiaries and other stakeholders to maintain or expand it. Similarly, governments with relatively expansive commitments to social protection and services are also likely to face greater constraints on spending, even in the face of economic and political shocks, such as financial crises or democratization. Where taxing capacity is limited and social spending is high, we expect the politics of social policy to be closely intertwined with more general pressures for fiscal consolidation. Conversely, in countries where taxes are adequate to meet spending commitments, and where those public commitments had previously been minimal, the overall fiscal stance of the government provides more room to expand commitments.

\section{Revenues}

We begin by considering the determinants of revenue, in effect the underlying fiscal capacity of the state (Table 2). We expect revenue to be positively correlated with wealth, measured as per capita GDP, and both openness to trade and the share of fuel and mineral exports in total exports. Trade, and particularly exports of fuels and minerals, are important sources of tax revenues in many developing countries because of their relative ease of collection. Net external financial transfers are also included, but their expected effect on the tax base is ambiguous. Although they might have a positive effect on revenue, a growing literature has suggested that net transfers of some sorts, such as aid (Moore, 1998; Remmer, 2004) and remittances (Chaudhry, 1997) might diminish the incentives for governments to tax. Finally, Cheibub (1998) among others has noted that the size of the agricultural sector is an important structural factor that limits "tax handles" and thus should be negatively correlated with revenue. Since the size of the agricultural sector is closely correlated with GDP per capita, it cannot be included in the same model, but as can be seen its effects are negative and significant when entered separately. 
TABLE 2: Determinants of Revenue, 1980-2000

\begin{tabular}{|c|c|c|c|c|c|}
\hline \multirow[t]{2}{*}{ Trade } & 0,144 & 0,135 & 0,125 & 0,145 & 0,134 \\
\hline & $(7,24)^{\star \star \star}$ & $(6,26)^{\star \star \star}$ & $(5,22)^{\star \star \star}$ & $(7,67)^{\star \star \star}$ & $(6,67)^{\star \star \star *}$ \\
\hline \multirow{2}{*}{ Net Transfer/GDP } & $-0,305$ & $-0,225$ & $-0,407$ & $-0,354$ & $-0,444$ \\
\hline & $(1,27)$ & $(0,81)$ & $(1,70)^{*}$ & $(1,50)$ & $(1,64)$ \\
\hline \multirow[t]{2}{*}{ Per Capita GDP } & 0,001 & & 0,002 & 0,001 & 0,001 \\
\hline & $(2,81)^{\star \star *}$ & & $(2,90)^{* \star *}$ & $(3,29)^{\star \star \star}$ & $(2,66)^{* \star *}$ \\
\hline \multirow[t]{2}{*}{ Agriculture/GDP } & & $-0,228$ & & & \\
\hline & & $(3,81)^{\star \star *}$ & & & \\
\hline \multirow[t]{2}{*}{ Fuel+Mineral Exports/Exports } & 0,045 & 0,020 & 0,040 & 0,041 & 0,047 \\
\hline & $(2,13)^{* *}$ & $(0,90)$ & $(1,98)^{*}$ & $(1,92)^{*}$ & $(2,04)^{\star *}$ \\
\hline \multirow[t]{2}{*}{ Latin America Dummy } & & & $-4,712$ & & \\
\hline & & & $(2,85)^{\star \star \star}$ & & \\
\hline \multirow[t]{2}{*}{ East Asia Dummy } & & & & $-6,535$ & \\
\hline & & & & $(3,15)^{\star \star \star}$ & \\
\hline \multirow[t]{2}{*}{ Eastern Europe Dummy } & & & & & 6,006 \\
\hline & & & & & $(2,34)^{* *}$ \\
\hline \multirow[t]{2}{*}{ Constant } & 7,789 & 16,707 & 9,761 & 8,075 & 8,196 \\
\hline & $(5,12)^{\star \star \star}$ & $(5,84)^{\star \star \star}$ & $(5,29)^{\star \star \star}$ & $(5,29)^{\star \star *}$ & $(5,58)^{\star \star \star}$ \\
\hline Observations & 102 & 103 & 102 & 102 & 102 \\
\hline R-squared & 0,53 & 0,54 & 0,56 & 0,56 & 0,58 \\
\hline
\end{tabular}

Robust $t$ statistics in parentheses.

* Significant at $10 \% ;{ }^{* *}$ significant at $5 \% ;{ }^{* * *}$ significant at $1 \%$

The general model, whether with agriculture as a share of GDP or GDP per capita, explains over half of the variance in average revenues and those two key variables enter as significant and strong predictors. Trade is also very highly significant in both of these models, and the share of fuel and mineral exports enters significantly in the model with GDP per capita and in all of the models with regional dummies. We did not find that net transfers had perverse effects on revenues except in the model with a Latin American dummy.

Columns 3-5 of Table 2 show the effects of dummy variables for each of the three regions of interest to us; we enter them separately so that each region is compared to all other countries in the sample. Even when controlling for the structural factors discussed above, we see intriguing cross-regional 
differences in fiscal capacity, or preferences over taxation. Not surprisingly, average revenue in the former socialist countries is significantly higher than in the other countries in the sample. Even following the transition and the substantial reforms of the 1990s, the former socialist states remained relatively large. By contrast, both the Latin America and East Asian countries tend to extract lower revenues than other countries in the sample; we explore these differences in more detail below by examining the differences between predicted and actual values for particular countries.

These findings, however, must be read in conjunction with our findings with respect to spending patterns. In the Asian countries, relatively low taxes have been matched by relatively conservative government spending and minimal social policy commitments. By contrast, Latin American countries tended to combine relatively low revenues with higher-than-predicted spending. Thus, although the Eastern European countries faced wrenching fiscal adjustments in the 1990s, the mismatch between spending and revenue, and the corresponding structural pressures on fiscal policy in general and social policy in particular, appear equally if not more marked in Latin America.

\section{Spending}

Table 3 shows the results of models of spending over the period from 1980 to 2000, with observations for between 61 and 89 countries. The capacity to generate revenues, as suggested above, is an explanatory factor of major substantive interest. Of course, political and social demands for spending can also drive taxation. However, Granger causality tests produce no evidence of endogeneity; lagged revenue has a significant, positive effect on expenditure, but lagged spending has no comparable effect on revenue. Thus, it is plausible to assume, at least for this sample and over the long run, that spending is constrained by the capacity of governments to extract resources from the economy rather than the other way around.

In addition to revenues, we include measures of a number of other demographic and structural factors. GDP per capita controls for the "Wagner's law" proposition that the demand for public services increases as countries become wealthier. We also include trade openness and net transfers as potential sources of spending. Our revenue models indicate that trade openness may affect spending through its effect on revenue. But openness may also affect spending directly, either through increased demands for social protection or alternatively and conversely, through pressures to reduce labor costs.

Two additional variables provide a preliminary means of assessing the political determinants of spending. The first is democracy, which is measured as the proportion of years during the sample period that exceeded a score of 6 on the combined Polity IV measure. The panel models in the next section provide a clearer picture of the effects of democratic transitions, since the units of analysis are country-years, rather than the period as a whole. Nevertheless, the measure we have chosen seems the best option for this type of cross-sectional analysis. We also include volatility of GDP as a proxy for the demand side of the political market, since this has been cited in a variety of studies as a possible determinant of spending (Mares, 2003).

Other controls, finally, include demographic factors related to age, a dummy for African countries which were large "overspenders" relative to their level of income, and a dummy for federal states in which some (unknown) share of total education and health spending takes place at the subnational level. 
TABLE 3: Determinants of Spending, 1980-2000

\begin{tabular}{|c|c|c|c|c|}
\hline & Expenditure & Education & Health & Social Security \\
\hline \multirow[t]{2}{*}{ Revenue } & 1,140 & 0,128 & 0,098 & 0,111 \\
\hline & $(10,17)^{\star \star *}$ & $(4,60)^{* * *}$ & $(4,46)^{* \star *}$ & $(2,09)^{\star *}$ \\
\hline \multirow[t]{2}{*}{ Trade } & $-0,004$ & 0,016 & 0,005 & $-0,017$ \\
\hline & $(0,17)$ & $(2,59)^{* *}$ & $(1,32)$ & $(1,41)$ \\
\hline \multirow[t]{2}{*}{ Net Transfer/GDP } & 1,356 & $-0,171$ & 0,035 & 0,043 \\
\hline & $(3,51)^{* * *}$ & $(3,39)^{* * *}$ & $(0,70)$ & $(0,59)$ \\
\hline \multirow[t]{2}{*}{ GDP per Capita } & $-0,001$ & 0,000 & 0,000 & 0,000 \\
\hline & $(1,42)$ & $(1,56)$ & $(0,54)$ & $(0,24)$ \\
\hline \multirow[t]{2}{*}{ Africa Dummy } & 1,126 & 0,156 & $-0,005$ & $-0,653$ \\
\hline & $(0,73)$ & $(0,34)$ & $(0,02)$ & $(1,19)$ \\
\hline \multirow[t]{2}{*}{ Population < 14} & $-0,151$ & 0,094 & 0,023 & 0,065 \\
\hline & $(1,04)$ & $(2,17)^{\star *}$ & $(0,72)$ & $(0,73)$ \\
\hline \multirow[t]{2}{*}{ Population > 65} & $-0,550$ & $-0,202$ & 0,003 & 1,038 \\
\hline & $(1,42)$ & $(1,95)^{*}$ & $(0,03)$ & $(5,59)^{* * *}$ \\
\hline \multirow[t]{2}{*}{ Federalism Dummy } & 3,593 & $-0,994$ & $-0,651$ & $-0,279$ \\
\hline & $(1,73)^{*}$ & $(1,94)^{*}$ & $(2,02)^{* *}$ & $(0,28)$ \\
\hline \multirow[t]{2}{*}{ Volatility } & 0,066 & 0,047 & 0,056 & $-0,040$ \\
\hline & $(0,47)$ & $(0,45)$ & $(0,59)$ & $(0,23)$ \\
\hline \multirow[t]{2}{*}{ Polity (proportion) } & $-1,407$ & 0,467 & 1,432 & 0,397 \\
\hline & $(0,79)$ & $(1,01)$ & $(3,13)^{* * *}$ & $(0,56)$ \\
\hline \multirow[t]{2}{*}{ Constant } & 9,919 & $-3,076$ & $-2,436$ & $-5,651$ \\
\hline & $(1,65)$ & $(1,50)$ & $(1,61)$ & $(1,34)$ \\
\hline Observations & 108 & 73 & 73 & 70 \\
\hline R-squared & 0,82 & 0,65 & 0,55 & 0,82 \\
\hline
\end{tabular}

Robust $t$ statistics in parentheses.

* Significant at, $1 ;{ }^{* *}$ significant at,05; ** significant at,01, 
The results presented in Table 3. Revenue, as expected, is a consistent predictor of spending, and the impact is significant across all categories of spending. Substantively, a one percentage point increase in revenue produces a 1.23 percentage point increase in central government expenditure, an increase of 4.2 percent for a country with an average level of revenue. The corresponding changes in health spending (0.08), education (0.09) and social security spending (0.13) appear much more modest when expressed as a share of GDP. But spending on those categories is also a relatively small share of total spending, and so this result is not surprising. These changes represent a 4.1 percent increase in health spending, a 2.4 percent increase in education spending, and a 3.1 percent increase in social security. It is nonetheless interesting to note that with the exception of health spending, increases (and decreases) in revenue have a more modest impact on social spending than they do on aggregate spending; this is consonant with the descriptive statistics cited above that suggest that aggregate spending is more volatile than social spending.

In addition to the effects of revenue, the most noteworthy results are the effects of trade openness on social spending. We find positive and significant effects in the education models, and the coefficient is positive in the health model as well. More open countries appear to invest more in education, perhaps because of ongoing pressures to maintain and upgrade human capital. ${ }^{1}$ In the social security model, the coefficient for trade openness is not significant, but the negative sign and t-statistic suggest the plausibility of the argument that more trade-dependent countries may be under pressure to limit social security commitments that have an adverse effect on the total wage bill.

An examination of other variables in the model shows a more mixed picture. The coefficients on the democracy variable are positive in all three spending categories but are only significant with respect to health spending. As noted, however, the proportion of democratic years over the period may be hiding within-country differences resulting from regime change. Although the demographic variables are not significant in the health models, the coefficients are more or less as expected in education and social security; countries with younger populations spend more on education and countries with older populations spend more on social security. Consistent with findings by Swank (2001), federalism appears to dampen spending in health and education, although it is not clear how much of the slack may be taken up by local spending. Results for GDP per capita, net transfers, and volatility are either not significant or go in opposite directions across spending categories. Despite these mixed results, however, the overall fit of these models is extremely good; for expenditure and social security, the R-square reaches.82.

\section{Inter- and intra-regional variation in revenue and spending}

The cross-section models reported above provide a baseline for assessing differences in fiscal commitments associated with the welfare systems of each of the three regions. Our first approach was to use regional dummies, as we did in the revenue models. Although the coefficients did not always reach standard significance thresholds, the signs were typically in the expected direction. For example, Latin America spent more in aggregate and on health and significantly more on social

We conducted a similar Granger causality test to see if the causal relationship might run the other way. This test is far from perfect, given that educational investments take a long time to mature, but as with our discussion of the relationship between spending and revenue, we found that while openness Granger caused education and health spending, the opposite was not the case. 
security (at the.05 level), while the coefficient on the regional dummy with respect to education was negative. In East Asia, the signs on all the coefficients were precisely the opposite of those for Latin America. The coefficients for education were positive although not significant, while governments spent less overall (significant at the.1 level) and on social security (significant at the. 05 level). Coefficients for spending on health were also negative, although these did not reach standard levels of significance. With respect to Eastern Europe, the regional coefficient with respect to aggregate spending was negative and significant (.1 level); once controlling for the high level of revenue, the former socialist countries did not spend more than predicted. The signs on both health and social security, by contrast, were positive.

In Tables 4 and 5 we compare actual revenue and spending in the countries of interest to us with values generated by the models. We standardized the residuals through a t-test-the residual divided by the standard deviation of the residual-and set a confidence interval of.10 to identify the countries that collected significantly more or less revenue, or spent significantly more or less, than predicted by the respective models.

Despite the very strong overall fit of the cross-sectional models, some interesting regional variance remains. This can be seen by focusing first on the "fit" between aggregate spending and revenue. In all of our Eastern European countries except the Czech Republic, actual revenues were significantly higher than those predicted by our revenue model. Over the course of the 1990s, revenue did decline significantly (see Table 1) as the transition toward more market-oriented economies shrank the state sector. Averaged over the decade, however, revenues continued to reflect the socialist legacy. As the positive coefficient on the regional dummy in the revenue model suggested, average revenues in the Eastern European countries remained higher than predicted even when controlling for other possible determinants. On the other hand, Table 5 shows that, with the exception of Poland, the socialist countries of interest to us did not spend more than predicted given their level of revenues and the other explanatory factors considered in the model. Romania actually spent significantly less.

In Asia the patterns are somewhat more dispersed. Malaysia and Indonesia, which we have included here, collected higher-than-predicted revenues; Thailand, the Philippines, and Korea collected less. As Table 5 shows, however, spending commitments were also typically lower than predicted. Of the five cases, only Korea shows both lower-than-predicted revenues and higher-than-predicted central government spending, and as we will see this was clearly not driven by unusually high social sector commitments.

In Latin America, finally, we find evidence that would suggest strong constraints on government emanating from both the revenue and spending side of the fiscal equation. On the revenue side, Brazil and Uruguay generate significantly higher than expected revenues (Table 4), but central government expenditures in those countries are also significantly higher than expected. On the other hand, revenues are chronically low in Argentina, Mexico, Colombia, Costa Rica, Peru, and Venezuela. Yet in all of these countries except Venezuela, spending exceeds what might have been expected, controlling for levels of revenue and other factors included in the spending model. Only "neo-liberal" Chile stands out within the region as a somewhat exceptional case. Revenues exceed expectations, but central government spending is lower than predicted. This analysis comports with other accounts of the relatively strong fiscal position the country maintained during the 1980s and 1990s. 
TABLE 4: Predicted and Actual Revenue, 1980-2000

\begin{tabular}{|c|c|}
\hline $\begin{array}{l}\text { Collected significantly more revenue than } \\
\text { predicted }\end{array}$ & $\begin{array}{l}\text { Collected significantly less revenue than } \\
\text { predicted }\end{array}$ \\
\hline Latin America: Brazil, Uruguay, Chile & $\begin{array}{l}\text { Latin America: Argentina, Colombia, Costa } \\
\text { Rica, Mexico, Peru, Venezuela }\end{array}$ \\
\hline East Asia: Malaysia, Indonesia & East Asia: Korea, Philippines, Thailand \\
\hline $\begin{array}{l}\text { Eastern Europe: Bulgaria, Hungary, Poland, } \\
\text { Romania, Slovakia }\end{array}$ & Eastern Europe: Czech Republic \\
\hline
\end{tabular}

* $\quad$ For countries listed in italics, predicted value is different than actual value at the $10 \%$ level. 
With respect to health and social security spending, a handful of countries from Latin America and Eastern Europe emerge as high spenders in one area or the other: Costa Rica, Brazil, Uruguay and Chile, with its historical inheritance of social security spending, Poland with respect to both social security and health, the Czech and Slovak republics with respect to health. In sum, the residuals suggest that a number of countries in Latin America and Eastern Europe had both higher levels of aggregate spending than predicted, as well as more substantial commitments to both health and social security spending. By contrast, no Asian countries spent significantly more than predicted in these two areas, and Korea spent less in both. With respect to education, by contrast, Korea and Thailand both spent more than predicted, although (to our surprise) Colombia, Mexico, Peru did as well.

Differences among the countries within each of the three regions underscore the need to examine intra-regional as well as cross-regional variations in spending patterns. Nevertheless, our analysis vindicates our suspicion that historical legacies associated with very development models continued to influence how countries confronted the global and political changes of the 1980s and 1990s. These inherited constraints, to be sure, involved a wide variety of organizational issues and were by no means limited to fiscal policy. Nevertheless, fiscal constraints provide the context for understanding how specific countries confronted the tradeoffs between redistribution and efficiency, or between what we call equity-enhancing and rationalizing reforms.

At one end of the spectrum were the countries of East Asia. The expansion of public commitments to social insurance and services depended, ultimately, on political factors including democratization and challenges to the conservative political forces that had long dominated politics. Nevertheless, decades of relatively cautious fiscal policy, limited spending commitments and continued high growth left new democratic governments in a better position to respond to pressures for expansion than their counterparts in other regions. Social spending did, for the most part, expand during the 1990s at a substantially faster pace than GDP growth (see Table 1).

In the formerly socialist Eastern European countries, governments sustained large welfare commitments and in some cases initially even expanded them. This was possible in part because most countries in the region also continued to draw on a revenue base that was substantially larger than in other countries at comparable levels of economic development. Nonetheless, despite some reduction in social spending over the course of the 1990s, these commitments placed serious strains on fiscal policy in a number of countries. When and where they did, they became the object of a contentious politics of rationalization.

Finally, the countries of Latin America experienced chronic fiscal constraints over the course of the 1980 s and 1990s. In a context of stagnant or even declining GDP, most countries struggled with low effective rates of taxation and higher spending commitments than comparable countries in our global sample. Economic stagnation placed strong social demands on governments, but left little room for a simple expansion of existing programs despite strong political and social pressures to do so. Rather, most countries in the region faced strong pressures to initiate structural reforms that would increase the efficiency as well as the equity of social services, insurance and safety nets. 


\section{THE DYNAMICS OF SOCIAL SPENDING, 1980-2000: A PANEL MODEL}

The cross-sectional analysis in the preceding section underscores the significance of structural differences across countries in prior fiscal commitments and the capacity to tax. However, it does not allow us to examine the effects of more contemporaneous constraints-changes in revenues and capital flows- on social spending. In the OECD, the gradual accretion of social entitlements, the relative breadth of the tax base, and the relative ease of borrowing have combined to make both fiscal and social policy countercyclical (Arreaza, Sorenson and Yosha, 1999; Hallerberg and Strauch, 2002). In the developing countries, by contrast, these automatic stabilizers are absent. ${ }^{2}$ Most citizens lack social entitlements that offset the adverse effects of the business cycle or other shocks. The revenue base of developing countries is more fragile than in the OECD, and the developing world's access to capital markets has proven highly volatile over the last two decades. Periods of booming capital inflows have alternated with severe financial crises and fiscal adjustments in all three regions.

We might therefore expect to find a pro-cyclical bias in government spending. A crucial question for social policy is the extent to which this pro-cyclical bias affects social spending (see Wibbels, 2003 on Latin America). Do governments protect social expenditure, or is it subject to volatility associated with the business cycle and other shocks? Again, we might expect pressures on spending would be more severe in countries (and in regions such as Latin America) that have inherited longterm structural imbalances between the revenue base and social spending commitments, although these relationships might also be mediated by political factors such as the extent of democracy.

In this section, we try to capture some of the dynamics of the period under consideration through a pooled time series analysis. In the discussion that follows, we are interested in three sets of issues:

1. To what extent do we see evidence of pro- or counter-cyclical fiscal behavior and what effect, if any, does this have on social spending?

2. To what extent was spending influenced - either positively or negatively - by globalization, operationalized as openness to trade and availability of external financing?

3. To what extent were democracies more likely to increase or protect social spending, given these other constraints?

The results we report here use a panel corrected standard errors (PCSE) approach (Beck and Katz, $1995,1996)$, which addresses problems of autocorrelation and heteroskedasticity. ${ }^{3}$ The PCSE model has been used in a number of other studies of government expenditure in the advanced industrial states (Iverson 2001; Swank, 2001). The dependent variable is the first-difference change in spending; this is regressed against both lagged change and lagged levels of the explanatory variables. As Iverson $(2001,64)$ explains, "the parameter for a level variable shows the permanent

We are indebted to Erik Wibbels for underlining these points to us; see Wibbels, 2003.

We also tested a country fixed effects model, but the results were not substantively different for the Asian and Latin American samples. The substantive effects of a country fixed effects approach is not altogether clear. Unmodeled country effects would have to influence he change, not the level of spending. Constraints on the degrees of freedom prevented us from using the country fixed effects in the post-socialist sample. 
(or long-term) effect of a one-off change in that variable, whereas the parameter for a change variable shows the transitory (short-term) effect of a one-off change in that variable." ${ }^{\prime 4}$

The substantive specification of the independent variables is broadly similar to the cross-sections. We consider the level and change in per capita GDP, and net transfers, as well as the appropriate demographic and population controls. "Democracy" is specified as a dummy variable: 1 if the score is 6 or more on the Polity IV democracy-authoritarian scale, and 0 if it falls below that level.

Trade openness (exports and imports/GDP) is measured in two ways, in terms of purchasing power parity (PPP), and in terms of a conversion to constant US dollars. Avelino, Brown, and Hunter (2003) have criticized measures based on conversion of GDP at current exchange rates, arguing that they overstate the extent of openness by underestimating the contribution of the nontraded goods sector to GDP. Particularly for low-income countries, they argue it is more accurate to calculate GDP in purchasing power parity (PPP) terms, and they show that the use of this openness measure produces very different results when used to analyze spending in a sample of Latin American countries. Since this measurement issue remains unsettled, we have run all models using measures of trade openness/GDP at current exchange rates and at PPP.

Meaningful tests on a global sample of countries is precluded by large amounts of missing data in Africa and other regions of the world. We therefore focus exclusively on the three regional subsamples which are in any case of primary interest to us (Tables 6, 7, and 8). ${ }^{5}$ Following our discussion in the preceding section, we pay special attention to differences across these samples. For purposes of presentation, we show only the coefficients for variables of substantive interest; controls for demography, wealth, and population size are omitted, but generally go in the expected direction and reach appropriate thresholds of significance.

4 In addition to aggregate government spending and the social spending categories of interest to us, we also include the results for models of government consumption. In contrast to government spending, which is for the central government, government consumption captures all levels of government and thus provides at least a partial corrective for the problem of gauging government spending in federal systems; the models for expenditure and consumption generally yielded quite similar results.

5 In addition to the data from the World Development Indicators that we used for the cross-sections, we have also tested our hypotheses on two other regional data sets; one for Latin America from CEPAL, the second on the former socialist countries from the European Bank for Reconstruction and Development. Particularly for the socialist sample, the overlap between the two data sets was surprisingly low because of somewhat different country coverage although the results were broadly comparable. 
TABLE 6: Aggregate and Social Spending in Latin America, 1980-2000 (PCSE Model)

\begin{tabular}{lccllllll}
\multicolumn{3}{c}{ Expenditure } & \multicolumn{2}{c}{ Education } & \multicolumn{3}{c}{ Health } & \multicolumn{3}{c}{ Social Security } \\
\hline Lag DV & $-0,320$ & $-0,331$ & $-0,153$ & $-0,182$ & $-0,122$ & $-0,116$ & $-0,173$ & $-0,229$ \\
Level & $(4,67)^{* * *}$ & $(4,65)^{* * *}$ & $(2,70)^{* * *}$ & $(2,77)^{* * *}$ & $(3,09)^{* * *}$ & $(2,83)^{* * *}$ & $(3,49)^{* * *}$ & $(4,06)^{* * *}$ \\
Lag Polity & 0,494 & 0,569 & 0,094 & 0,178 & $-0,018$ & $-0,032$ & 0,033 & 0,109 \\
& $(1,27)$ & $(1,33)$ & $(0,94)$ & $(1,61)$ & $(0,29)$ & $(0,55)$ & $(0,25)$ & $(0,81)$ \\
Lag Revenue & 0,359 & 0,395 & 0,031 & 0,025 & 0,019 & 0,015 & 0,069 & 0,102 \\
Level & $(4,30)^{* * *}$ & $(4,42)^{* * *}$ & $(1,82)^{*}$ & $(1,47)$ & $(3,05)^{* * *}$ & $(2,16)^{* *}$ & $(3,07)^{* * *}$ & $(3,61)^{* * *}$ \\
Revenue & 0,359 & 0,369 & 0,054 & 0,046 & 0,039 & 0,037 & 0,074 & 0,083 \\
Change & $(3,54)^{* * *}$ & $(3,60)^{* * *}$ & $(2,16)^{* *}$ & $(1,83)^{*}$ & $(3,14)^{* * *}$ & $(2,90)^{* * *}$ & $(2,33)^{* *}$ & $(2,44)^{* *}$ \\
PCGDP & 0,000 & 0,000 & 0,000 & 0,000 & 0,000 & 0,000 & 0,001 & 0,001 \\
Change & $(0,48)$ & $(0,25)$ & $(1,30)$ & $(1,21)$ & $(0,39)$ & $(0,66)$ & $(1,82)^{*}$ & $(1,44)$ \\
Lag Trade & $-0,022$ & & 0,001 & & 0,002 & & $-0,012$ & \\
Level & $(1,49)$ & & $(0,39)$ & & $(0,86)$ & & $(1,99)^{* *}$ & \\
Lag Trade & & $-0,018$ & & 0,005 & & 0,003 & & $-0,007$ \\
Level (PPP) & & $(1,41)$ & & $(1,82)^{*}$ & & $(1,50)$ & & $(1,73)^{*}$ \\
Lag Net & 0,085 & 0,077 & 0,007 & 0,013 & $-0,004$ & $-0,004$ & 0,043 & 0,055 \\
Transfers & $(1,79)^{*}$ & $(1,51)$ & $(0,48)$ & $(0,90)$ & $(0,55)$ & $(0,51)$ & $(2,30)^{* *}$ & $(2,83)^{* * *}$ \\
Change Net & 0,000 & 0,008 & $-0,003$ & $-0,006$ & $-0,001$ & $-0,001$ & 0,005 & $-0,004$ \\
Transfers & $(0,00)$ & $(0,20)$ & $(0,32)$ & $(0,56)$ & $(0,13)$ & $(0,13)$ & $(0,30)$ & $(0,23)$ \\
Constant & $-2,412$ & $-6,772$ & $-1,764$ & $-1,235$ & 1,712 & 1,304 & 0,139 & $-2,856$ \\
& $(0,29)$ & $(1,00)$ & $(1,14)$ & $(0,78)$ & $(1,20)$ & $(1,01)$ & $(0,04)$ & $(1,15)$ \\
\hline Observations & 238 & 218 & 131 & 125 & 174 & 168 & 170 & 164 \\
R-Squared & 0,24 & 0,25 & 0,19 & 0,19 & 0,16 & 0,19 & 0,23 & 0,20 \\
\hline
\end{tabular}

* Significant at $10 \% ;{ }^{* *}$ significant at $5 \% ;{ }^{* *}$ significant at $1 \%$

TABLE 7: Aggregate and Social Spending in Asia, 1980-2000 (PCSE Model)

\begin{tabular}{|c|c|c|c|c|c|c|c|c|}
\hline & Expenditure & & Education & & Health & & Soc & urity \\
\hline $\begin{array}{l}\text { Lag DV } \\
\text { Level }\end{array}$ & $\begin{array}{l}-0,455 \\
(6,13)^{* * *}\end{array}$ & $\begin{array}{l}-0,364 \\
(5,04)^{* * *}\end{array}$ & $\begin{array}{l}-0,453 \\
(4,83)^{\star \star * *}\end{array}$ & $\begin{array}{l}-0,489 \\
(4,63)^{\star * * *}\end{array}$ & $\begin{array}{l}-0,131 \\
(1,35)\end{array}$ & $\begin{array}{l}-0,125 \\
(1,23)\end{array}$ & $\begin{array}{l}-0,768 \\
(3,92)^{\star * *}\end{array}$ & $\begin{array}{l}-0,832 \\
(4,38)^{\star * *}\end{array}$ \\
\hline Lag Polity & $\begin{array}{c}0,893 \\
(2,41)^{\star *}\end{array}$ & $\begin{array}{c}1,039 \\
(2,94)^{\star * *}\end{array}$ & $\begin{array}{c}0,431 \\
(3,28)^{\star \star *}\end{array}$ & $\begin{array}{c}0,424 \\
(3,03)^{\star \star \star}\end{array}$ & $\begin{array}{c}0,014 \\
(0,19)\end{array}$ & & $\begin{array}{c}0,224 \\
(1,65)^{*}\end{array}$ & $\begin{array}{l}0,262 \\
(2,05)^{\star *}\end{array}$ \\
\hline $\begin{array}{l}\text { Lag Revenue } \\
\text { Level }\end{array}$ & $\begin{array}{l}0,516 \\
(4,98)^{\star * *}\end{array}$ & $\begin{array}{c}0,330 \\
(2,76)^{\star * *}\end{array}$ & $\begin{array}{l}-0,049 \\
(2,09)^{\text {* * }}\end{array}$ & $\begin{array}{l}-0,014 \\
(0,53)\end{array}$ & $\begin{array}{l}-0,013 \\
(1,37)\end{array}$ & $\begin{array}{l}-0,014 \\
(1,28)\end{array}$ & $\begin{array}{l}0,077 \\
(3,75)^{* * *}\end{array}$ & $\begin{array}{c}0,073 \\
(3,83)^{\star * *}\end{array}$ \\
\hline $\begin{array}{l}\text { Revenue } \\
\text { Change }\end{array}$ & $\begin{array}{c}0,653 \\
(5,05)^{\star * *}\end{array}$ & $\begin{array}{c}0,528 \\
(4,16)^{\star * *}\end{array}$ & $\begin{array}{c}0,004 \\
(0,16)\end{array}$ & $\begin{array}{c}0,014 \\
(0,55)\end{array}$ & $\begin{array}{c}0,013 \\
(1,17)\end{array}$ & $\begin{array}{c}0,014 \\
(1,24)\end{array}$ & $\begin{array}{c}0,051 \\
(2,37)^{\star *}\end{array}$ & $\begin{array}{l}0,051 \\
(2,57)^{\star *}\end{array}$ \\
\hline $\begin{array}{l}\text { PCGDP } \\
\text { Change }\end{array}$ & $\begin{array}{l}-0,006 \\
(2,93)^{\star * *}\end{array}$ & $\begin{array}{l}-0,002 \\
(0,88)\end{array}$ & $\begin{array}{l}-0,001 \\
(3,62)^{\star * *}\end{array}$ & $\begin{array}{l}-0,001 \\
(2,46)^{\star *}\end{array}$ & $\begin{array}{l}0,000 \\
(1,10)\end{array}$ & $\begin{array}{c}0,000 \\
(0,62)\end{array}$ & $\begin{array}{l}-0,001 \\
(2,80)^{\star * *}\end{array}$ & $\begin{array}{l}-0,001 \\
(1,87)^{\star}\end{array}$ \\
\hline $\begin{array}{l}\text { Lag Trade } \\
\text { Level }\end{array}$ & $\begin{array}{l}-0,007 \\
(0,78)\end{array}$ & & $\begin{array}{c}0,008 \\
(1,77)^{\star}\end{array}$ & & $\begin{array}{c}0,002 \\
(1,53)\end{array}$ & & $\begin{array}{c}0,002 \\
(1,05)\end{array}$ & \\
\hline $\begin{array}{l}\text { Lag Trade } \\
\text { Level (PPP) }\end{array}$ & & $\begin{array}{l}-0,001 \\
(0,05)\end{array}$ & & $\begin{array}{l}-0,004 \\
(0,40)\end{array}$ & & $\begin{array}{c}0,004 \\
(1,19)\end{array}$ & & $\begin{array}{c}0,008 \\
(1,77)^{*}\end{array}$ \\
\hline $\begin{array}{l}\text { Lag Net } \\
\text { Transfers }\end{array}$ & $\begin{array}{l}-0,026 \\
(0,69)\end{array}$ & $\begin{array}{l}-0,096 \\
(2,57)^{\text {* }}\end{array}$ & $\begin{array}{c}0,049 \\
(5,53)^{\star * *}\end{array}$ & $\begin{array}{c}0,052 \\
(4,75)^{\star \star \star}\end{array}$ & $\begin{array}{l}0,008 \\
(2,45)^{* *}\end{array}$ & $\begin{array}{c}0,005 \\
(1,31)\end{array}$ & $\begin{array}{l}-0,010 \\
(1,37)\end{array}$ & $\begin{array}{l}-0,011 \\
(1,58)\end{array}$ \\
\hline $\begin{array}{l}\text { Change Net } \\
\text { Transfers }\end{array}$ & $\begin{array}{l}-0,031 \\
(0,79)\end{array}$ & $\begin{array}{c}0,022 \\
(0,52)\end{array}$ & $\begin{array}{l}-0,031 \\
(3,22)^{\star * *}\end{array}$ & $\begin{array}{l}-0,035 \\
(3,17)^{\star \star \star}\end{array}$ & $\begin{array}{l}-0,001 \\
(0,27)\end{array}$ & $\begin{array}{c}0,001 \\
(0,19)\end{array}$ & $\begin{array}{l}-0,008 \\
(1,16)\end{array}$ & $\begin{array}{l}-0,007 \\
(0,94)\end{array}$ \\
\hline Constant & $\begin{array}{l}-5,876 \\
(0,42)\end{array}$ & $\begin{array}{l}-2,724 \\
(0,24)\end{array}$ & $\begin{array}{l}11,584 \\
(2,51)^{\star *}\end{array}$ & $\begin{array}{l}15,870 \\
(3,44)^{\star * *}\end{array}$ & $\begin{array}{c}0,934 \\
(0,51)\end{array}$ & $\begin{array}{c}1,868 \\
(1,09)\end{array}$ & $\begin{array}{c}-11,394 \\
(4,44)^{* * *}\end{array}$ & $\begin{array}{c}-11,645 \\
(5,12)^{\star \star * *}\end{array}$ \\
\hline Observ & 88 & 83 & 51 & 50 & 60 & 59 & 46 & 45 \\
\hline R-Squared & 0,53 & 0,59 & 0,65 & 0,63 & 0,35 & 0,34 & 0,57 & 0,62 \\
\hline
\end{tabular}

* Significant at $10 \%$; * significant at $5 \% ;{ }^{* * *}$ significant at $1 \%$ 
TABLE 8: Aggregate and Social Spending in the Former Socialist Countries, 1990-2000 (PSCE Model)

\begin{tabular}{|c|c|c|c|c|c|c|c|c|}
\hline \multirow[b]{2}{*}{$\begin{array}{l}\text { Lag DV } \\
\text { Level }\end{array}$} & \multicolumn{2}{|c|}{ Expenditure } & \multicolumn{2}{|c|}{ Education } & \multicolumn{2}{|l|}{ Health } & \multicolumn{2}{|c|}{ Social Security } \\
\hline & $\begin{array}{l}-0,528 \\
(4,61)^{\star * *}\end{array}$ & $\begin{array}{l}-0,480 \\
(3,78)^{* * *}\end{array}$ & $\begin{array}{l}-0,584 \\
(5,09)^{* * *}\end{array}$ & $\begin{array}{l}-0,559 \\
(5,31)^{\star * *}\end{array}$ & $\begin{array}{l}-0,241 \\
(3,06)^{* * *}\end{array}$ & $\begin{array}{l}-0,253 \\
(2,70)^{* * *}\end{array}$ & $\begin{array}{l}-0,239 \\
(2,82)^{* * *}\end{array}$ & $\begin{array}{l}-0,190 \\
(2,05)^{\star *}\end{array}$ \\
\hline Lag Polity & $\begin{array}{c}0,984 \\
(1,61)\end{array}$ & $\begin{array}{c}1,826 \\
(1,94)^{*}\end{array}$ & $\begin{array}{l}-0,277 \\
(1,17)\end{array}$ & $\begin{array}{l}-0,330 \\
(1,14)\end{array}$ & $\begin{array}{c}0,427 \\
(2,22)^{\star *}\end{array}$ & $\begin{array}{c}0,415 \\
(2,02)^{* *}\end{array}$ & $\begin{array}{c}0,663 \\
(1,47)\end{array}$ & $\begin{array}{c}0,664 \\
(1,37)\end{array}$ \\
\hline $\begin{array}{l}\text { Lag Revenue } \\
\text { Level }\end{array}$ & $\begin{array}{c}0,588 \\
(5,54)^{\star * *}\end{array}$ & $\begin{array}{c}0,584 \\
(3,30)^{\star * *}\end{array}$ & $\begin{array}{l}-0,016 \\
(0,48)\end{array}$ & $\begin{array}{c}0,025 \\
(1,04)\end{array}$ & $\begin{array}{c}0,005 \\
(0,17)\end{array}$ & $\begin{array}{c}0,004 \\
(0,15)\end{array}$ & $\begin{array}{r}0,060 \\
(0,83)\end{array}$ & $\begin{array}{c}0,032 \\
(0,42)\end{array}$ \\
\hline $\begin{array}{l}\text { Revenue } \\
\text { Change }\end{array}$ & $\begin{array}{c}0,957 \\
(6,99)^{* * *}\end{array}$ & $\begin{array}{c}1,014 \\
(5,38)^{\star * *}\end{array}$ & $\begin{array}{l}-0,008 \\
(0,20)\end{array}$ & $\begin{array}{c}0,022 \\
(0,60)\end{array}$ & $\begin{array}{c}0,086 \\
(2,29)^{\star *}\end{array}$ & $\begin{array}{c}0,083 \\
(2,46)^{* *}\end{array}$ & $\begin{array}{l}-0,009 \\
(0,09)\end{array}$ & $\begin{array}{l}-0,009 \\
(0,09)\end{array}$ \\
\hline $\begin{array}{l}\text { Lag Per } \\
\text { Capita GDP }\end{array}$ & $\begin{array}{c}0,000 \\
(0,26)\end{array}$ & $\begin{array}{c}0,000 \\
(0,45)\end{array}$ & $\begin{array}{c}0,000 \\
(3,96)^{\star \star *}\end{array}$ & $\begin{array}{c}0,000 \\
(2,60)^{\star * *}\end{array}$ & $\begin{array}{l}-0,000 \\
(0,16)\end{array}$ & $\begin{array}{c}0,000 \\
(0,07)\end{array}$ & $\begin{array}{c}0,000 \\
(0,92)\end{array}$ & $\begin{array}{c}0,000 \\
(1,34)\end{array}$ \\
\hline $\begin{array}{l}\text { PCGDP } \\
\text { Change }\end{array}$ & $\begin{array}{l}-0,001 \\
(1,61)\end{array}$ & $\begin{array}{l}-0,000 \\
(2,47)^{* *}\end{array}$ & $\begin{array}{l}-0,001 \\
(1,72)^{*}\end{array}$ & $\begin{array}{l}-0,000 \\
(0,84)\end{array}$ & $\begin{array}{c}0,001 \\
(1,97)^{* *}\end{array}$ & $\begin{array}{c}0,001 \\
(1,74)^{*}\end{array}$ & $\begin{array}{l}-0,000 \\
(0,09)\end{array}$ & $\begin{array}{l}-0,001 \\
(1,48)\end{array}$ \\
\hline $\begin{array}{l}\text { Lag Trade } \\
\text { Level }\end{array}$ & $\begin{array}{l}-0,048 \\
(3,45)^{* * *}\end{array}$ & & $\begin{array}{l}-0,011 \\
(1,62)\end{array}$ & & $\begin{array}{l}-0,000 \\
(0,04)\end{array}$ & & $\begin{array}{l}-0,014 \\
(1,11)\end{array}$ & \\
\hline $\begin{array}{l}\text { Lag Trade } \\
\text { Level (PPP) }\end{array}$ & & $\begin{array}{l}-0,080 \\
(1,17)\end{array}$ & & $\begin{array}{l}-0,017 \\
(0,93)\end{array}$ & & $\begin{array}{l}-0,006 \\
(0,30)\end{array}$ & & $\begin{array}{l}-0,032 \\
(0,63)\end{array}$ \\
\hline $\begin{array}{l}\text { Lag Net } \\
\text { Transfers }\end{array}$ & $\begin{array}{l}-0,053 \\
(0,66)\end{array}$ & $\begin{array}{l}-0,078 \\
(0,84)\end{array}$ & $\begin{array}{l}-0,010 \\
(0,46)\end{array}$ & $\begin{array}{c}0,002 \\
(0,09)\end{array}$ & $\begin{array}{c}0,002 \\
(0,12)\end{array}$ & $\begin{array}{c}0,001 \\
(0,07)\end{array}$ & $\begin{array}{c}0,013 \\
(0,26)\end{array}$ & $\begin{array}{c}0,011 \\
(0,23)\end{array}$ \\
\hline $\begin{array}{l}\text { Change Net } \\
\text { Transfers }\end{array}$ & $\begin{array}{l}-0,123 \\
(2,04)^{* *}\end{array}$ & $\begin{array}{l}-0,176 \\
(2,02)^{* *}\end{array}$ & $\begin{array}{l}-0,004 \\
(0,24)\end{array}$ & $\begin{array}{l}-0,005 \\
(0,28)\end{array}$ & $\begin{array}{l}-0,015 \\
(1,04)\end{array}$ & $\begin{array}{l}-0,016 \\
(0,98)\end{array}$ & $\begin{array}{l}-0,062 \\
(1,50)\end{array}$ & $\begin{array}{l}-0,063 \\
(1,39)\end{array}$ \\
\hline Constant & $\begin{array}{l}27,083 \\
(2,07)^{* *}\end{array}$ & $\begin{array}{c}15,076 \\
(0,80)\end{array}$ & $\begin{array}{c}9,023 \\
(1,53)\end{array}$ & $\begin{array}{c}2,754 \\
(0,68)\end{array}$ & $\begin{array}{l}19,757 \\
(2,21)^{* *}\end{array}$ & $\begin{array}{l}21,114 \\
(2,33)^{* *}\end{array}$ & $\begin{array}{c}3,624 \\
(0,32)\end{array}$ & $\begin{array}{c}6,622 \\
(0,64)\end{array}$ \\
\hline Observations & 95 & 63 & 50 & 45 & 50 & 45 & 50 & 45 \\
\hline R-Squared & 0,60 & 0,65 & 0,64 & 0,65 & 0,48 & 0,48 & 0,36 & 0,34 \\
\hline
\end{tabular}

* Significant at $10 \% ;{ }^{* *}$ significant at $5 \%$; ${ }^{* *}$ significant at $1 \%$

The most striking findings again concern revenue. The highly significant positive coefficients on the level of revenue in all three regional models of aggregate spending are consistent with the results of our cross-sections; they suggest the long-run constraint revenue places on the trend rate of spending growth. The coefficients on changes in revenue, by contrast, are revealing of pro- or counter-cyclical responses to short-term fluctuations in available fiscal resources. In all three regions, the positive coefficients on the change in revenue suggest that central government spending is also constrained by revenue in the short-run.

Consistent with our discussion of regional differences in the preceding section and with Wibbels (2003), Latin American countries appear most prone to revenue constraints. The strongest effect is on overall expenditures, as it is in the other regions as well. In Latin America, however, we see significant evidence of procyclical revenue constraints in all the social spending categories as well. Substantive effects are modest, but far from trivial; these effects are summarized in Table 9, where we calculate the effect of a one-off, one percentage point change in revenue on spending over a five year period. ${ }^{6}$ In social security, a one-off one percentage point decrease in revenue results in a 5 percent reduction in total social security expenditure as a share of GDP over five years. This reduction is equal to 0.26 percent of GDP, roughly equivalent in size to total spending on a major anti-poverty program such as PROGRESA in Mexico. The effects on education or more 
modest as a share of GDP, but even larger as a share of total spending, over 7 percent. As discussed in the preceding section, these patterns appear to reflect fiscal vulnerabilities that permitted very little room for countercyclical fiscal policy or protection of social spending.

In Eastern Europe and Asia, a similar decline in revenue also produces large cuts in aggregate central government spending. In these two regions, a one-off one percentage point decline in revenue yields a decline of 5 to 7 percent in aggregate expenditure measured as a percent of GDP. However, unlike in Latin America, these revenue-driven changes in aggregate spending do not carry over as consistently into the social spending categories. In Eastern Europe, the effects of revenue change on health spending is substantial; a one-percent decline in revenue leads to a cumulative five-year decline of about 8 percent in health spending as a share of GDP. The effects on other categories of social spending, however, do not reach standard levels of significance. In Asia, the effects of revenue change are insignificant in all spending categories except social security. Given the low level of social security spending to begin with, the decline is modest expressed as a share of GDP but nonetheless equals fully 7 percent of such spending.

TABLE 9: Cumulative Impact of One-Off Revenue Change* on Expenditure

\begin{tabular}{|c|c|c|c|c|}
\hline & $\begin{array}{l}\text { Significance } \\
\text { Level of } \\
\text { Revenue } \\
\text { Change }\end{array}$ & $\begin{array}{l}\text { Cumulative } \\
\text { Five-Year } \\
\text { Change in } \\
\text { Expenditure/ } \\
\text { GDP (A) }\end{array}$ & $\begin{array}{c}\text { Average } \\
\text { Expenditure/ } \\
\text { GDP (B) }\end{array}$ & $\begin{array}{l}\text { Cumulative } \\
\text { Change/ } \\
\text { Average } \\
\text { Expenditure/ } \\
\text { GDP (B) }\end{array}$ \\
\hline \multicolumn{5}{|l|}{ Latin America } \\
\hline Expenditure & $1 \%$ & 0,96 & 19,81 & $4,8 \%$ \\
\hline Education & $5 \%$ & 0,20 & 2,80 & $7,1 \%$ \\
\hline Health & $1 \%$ & 0,15 & 1,97 & $0,8 \%$ \\
\hline Social Security & $5 \%$ & 0,26 & 5,25 & $5,0 \%$ \\
\hline \multicolumn{5}{|l|}{ East Asia } \\
\hline Expenditure & $1 \%$ & 1,37 & 19,86 & $6,9 \%$ \\
\hline Education & Not Significant* * & & & \\
\hline Health & Not Significant* * & & & \\
\hline Social Security & $5 \%$ & 0,07 & 0,90 & $7,4 \%$ \\
\hline \multicolumn{5}{|l|}{ Eastern Europe } \\
\hline Expenditure & $1 \%$ & 1,57 & 33,68 & $4,6 \%$ \\
\hline Education & Not Significant ${ }^{* *}$ & & & \\
\hline Health & $5 \%$ & 0,31 & 3,44 & $9,0 \%$ \\
\hline Social Security & Not Significant ${ }^{* *}$ & & & \\
\hline
\end{tabular}

* One-off change of one percentage point of GNP

* * Not Significant at the $10 \%$ level

* Significant at $10 \%$; ${ }^{* *}$ significant at $5 \%$; ${ }^{* *}$ significant at $1 \%$ 
The coefficient for per capita growth is more difficult to interpret, because the variable functions in part to correct for the effects of growth on spending, which is expressed in all models as a share of GDP. Nevertheless, the results are at least in part consistent with the substantive interpretation of these cross-regional differences. In Latin America, the signs on growth are positive and near significance in expenditure and social security, again an indication of procyclicality. In Asia, the signs are generally negative and significant. In Eastern Europe, signs appear to be much more sensitive to specification, which suggests a more indeterminate impact.

The effects of trade openness are weaker and less consistent than those of revenues, but do point to some interesting conclusions. First, there is no evidence to support the contention of Cameron (1978), Rodrik (1997) and others that trade openness leads to increases in the overall size of the public economy. On the contrary, in all three regions, the coefficients were negative, as they also were in the cross-sectional model. This was true, moreover, for both the PPP and exchange-rate measures of openness.

Perhaps more interesting from our perspective are the implications about cross-regional differences in social security spending. Consistent with previous studies (Kaufman and Segura-Ubiergo, 2001) trade openness had a negative and significant impact on social security expenditures - the largest single component of the social spending budget in most countries. Trade openness may also have had a dampening effect on social security spending in the Eastern European countries (see also Frye, 2003), although the coefficients were not significant. Conversely, East Asian countries presumably those with fewer budget constraints - appear to have responded to the positive incentives for protection sometimes associated with trade openness; signs were positive and the PPP coefficient significant at the.1 level. These findings, we should add, were not highly robust to earlier specifications, suggesting that both the positive and negative effects of trade openness may be weaker than has sometimes been argued. Nevertheless, there do appear to be consistent differences in the cross-regional patterns of response.

The effects of trade openness on other spending categories are less suggestive, as are the general results for changes in net transfers (our measure of external financial constraints). Although trade openness was positively related to health and education spending in our cross-sectional analysis, coefficients in the change models show no clear pattern. Despite the tremendous volatility of capital flows experienced by all three regions, it is difficult to find consistent evidence that it had an effect on social spending.

The weakness of findings on net transfers again raises questions about the role that external financial constraints have had in shaping the public economy. Over the past decade, debates have turned on the question of whether trade and financial integration encourage governments to invest in social protections or control labor costs in order to maintain competitiveness. Our findings on trade openness lean mildly toward the latter hypothesis, at least with respect to social security, but the evidence on net transfers suggests that the constraints imposed by financial markets may be relatively loose.

The effects of democracy, finally, differ across the regions. The strongest effect appears to be in East Asia. In that region, the coefficient for Polity is positive and significant in all categories of spending except health, where the signs are also positive. A possible interpretation of this finding is, again, that relatively loose fiscal constraints allowed governments to be more responsive to popular 
demands for more social spending that arose in the wake of the transition to democratic rule. Such effects are much weaker in Eastern Europe, but the effects of democracy on health and social security spending are positive and either approach or exceed standard significance levels. In those areas, notwithstanding substantial fiscal constraints, democratic governments-clustered largely in Central Europe and the Baltics-appeared to respond to long-standing expectations for social protection.

In Latin America, on the other hand, Polity does not have an impact on any spending category. This may be an artifact of the high number of democratic years in Latin America for the period under examination; there was less variation of regime type during the 1980s and 1990s than there was in East Asia or in the former socialist countries during the 1990s. Again, however, this finding may also reflect the operation of exceptionally tight fiscal constraints that limited the freedom of new democratic governments to increase spending, even in the face of rising social demands.

\section{Do Democracies Dampen the Effect of Revenue Cycles?}

In this section, we address the question of whether democratic regimes are more likely than autocracies to protect spending during periods of fiscal constraint. To explore this issue, we focus on the extent to which the interaction between regime type and changes in revenue affects changes in spending.

In the model reported below, we have used a tripartite distinction between high democracies (between high democracies (with Polity scores of over 6), semi-democracies (Polity scores between 0 and 6), and autocracies (less than zero) in order to avoid problems of colinearity in the Latin American sample. Using the dichotomous measure, over 75 percent of the country years in Latin America were classified as democratic, which contributed to a high correlation between the democracy dummy and the interaction term. Making this tripartite distinction not only provides a way around a statistical problem, but also makes intuitive sense. Most of the observations in the semi-democracy category were in countries such as Guatemala, El Salvador, Mexico, and the Dominican Republic, semi-competitive regimes in which some electoral constraints operated. ${ }^{7}$

Tables 9, 10, and 11 show the coefficients for the variables of interest to us here: revenue change, regime type, and the interaction between them. All other variables in these models are the same as in the preceding tables (Tables 6-8), and showed very similar results; for simplicity of presentation we have therefore omitted them. Columns 1,3,5, and 7 of each table provide estimates when trade openness is measured using current exchange rates; columns 2,4,6, and 8 show results when trade openness is measured on a PPP basis.

The uninteracted coefficients for revenue change estimate the effect of this variable on spending in autocracies (ie., when Polity $=0$ ). The conditional coefficients shown at the bottom of the table show the effects of revenue change in high ("High Dem Cond. Effect") and semi-democracies ("Low Dem Cond. Effect") respectively and capture whether there is a "democracy effect" on spending in the context of changes in revenue. ${ }^{8}$ The $P$ statistic in the next row, in turn, estimates the significance of the difference between the effects of revenue change in autocracies and high democracies. It is

In Asia, semi-democracies were observed most often in Korea, Malaysia, and Thailand. In the post-Socialist countries, in Albania, Armenia, Georgia, Macedonia, and Russia.

These coefficients are calculated by adding the interaction term (regime* revenue change) to the coefficient for revenue change and adjusting the standard errors. 
important to underscore that the conditional effects of democracy and the P statistic are conveying different information. Even if high democracy does not have a statistically significant effect on its own, the difference between autocracies and high democracies may nonetheless be significant. Conversely, high democracy may have an independent effect, but that effect may not be significantly different from the effect in autocracies.

We look first at central government expenditures. In Eastern Europe, the effects are mixed; democracies appear to slightly reduce countercyclicality in one specification and to increase it in the other but the differences between autocracies and democracies is not great in either case. However, in both East Asia and Latin America, "high democracies" are more likely than autocracies to mitigate the procyclical effects of revenue change on aggregate government expenditures. Consistent with our general expectations, the "democracy effect" is most pronounced in the East Asian sample. In autocracies, a dollar decrease in revenue leads to a corresponding decrease of about 70 cents in central government expenditures (columns 1 and 2). But in high democracies, spending is not significantly affected by revenue change one way or the other, and the difference between the two types of regimes is strongly significant (P statistic $=.01-.03$ ). In Latin America's high democracies, revenue change continues to be positively associated with expenditures but the magnitude is only about half that of autocracies. For every dollar revenue declines, expenditures decline by about 60 cents in autocracies but only 30 cents in high democracies (columns 1 and 2).

The conditional effects of regime type are much weaker with respect to social spending. Such effects are most pronounced in Eastern Europe although the results are mixed. On the one hand, the effects of revenue change on health spending shifts from being moderately countercyclical in autocracies to mildly procyclical in democracies, a counterintuitive result. On the other hand, the results are exactly the opposite with respect to education spending. High democracies provide substantial protection to education during periods of contracting revenue. With respect to social security spending, the substantive effects are quite large and significant at the point. 05 level in the exchange rate model: a dollar decrease in revenue leads to an increase of 37 cents (this effect does not hold in the PPP model). In neither model is the difference between autocracies and democracies significant at standard thresholds.

In Latin America, the conditional coefficients for both low and high democracy are significant across all specifications with the sole exception of education spending in high democracy, but this is not significantly different from performance under autocracies. Indeed, if anything, the opposite is the case in some policy areas. In autocracies, the signs on the revenue coefficients for both education and social security are negative, whereas in democracies, the signs are positive, significantly, in the case of social security. These results, again, are consistent with the hypothesis that the fiscal vulnerabilities of the 1980s and 1990s left little room for new democracies to protect social spending. ${ }^{9}$ 
TABLE 10: Interaction of Revenue Change and Regime Type in Latin America (PCSE MODEL)

\begin{tabular}{|c|c|c|c|c|c|c|c|c|}
\hline \multicolumn{9}{|c|}{ Latin America PCSE Democracy Interactive Models; Hi-Lo Democracy } \\
\hline & \multicolumn{2}{|c|}{ Expenditure } & \multicolumn{2}{|c|}{ Education } & \multicolumn{2}{|c|}{ Health } & \multicolumn{2}{|c|}{ Social Security } \\
\hline & 1 & 2 & 3 & 4 & 5 & 6 & 7 & 8 \\
\hline Lag DV Level & $\begin{array}{l}-0,324 \\
(4,47)^{\star \star \star}\end{array}$ & $\begin{array}{l}-0,348 \\
(4,61)^{\star * *}\end{array}$ & $\begin{array}{l}-0,260 \\
(3,98)^{\star \star *}\end{array}$ & $\begin{array}{l}-0,266 \\
(3,57)^{\star \star *}\end{array}$ & $\begin{array}{l}-0,125 \\
(2,96)^{\star * *}\end{array}$ & $\begin{array}{l}-0,110 \\
(2,56)^{* *}\end{array}$ & $\begin{array}{l}-0,182 \\
(3,64)^{\star \star *}\end{array}$ & $\begin{array}{l}-0,233 \\
(4,14)^{\star \star *}\end{array}$ \\
\hline Lag Low Democracy & $\begin{array}{l}-0,292 \\
(0,43)\end{array}$ & $\begin{array}{l}-0,639 \\
(0,89)\end{array}$ & $\begin{array}{l}-0,257 \\
(1,91)^{\star}\end{array}$ & $\begin{array}{l}-0,077 \\
(0,57)\end{array}$ & $\begin{array}{l}-0,068 \\
(0,86)\end{array}$ & $\begin{array}{l}-0,017 \\
(0,21)\end{array}$ & $\begin{array}{r}0,169 \\
(0,83)\end{array}$ & $\begin{array}{c}0,045 \\
(0,20)\end{array}$ \\
\hline Lag High Dem & $\begin{array}{l}0,394 \\
(0,72)\end{array}$ & $\begin{array}{l}0,535 \\
(0,90)\end{array}$ & $\begin{array}{c}0,250 \\
(2,30)^{\star \star}\end{array}$ & $\begin{array}{l}0,364 \\
(3,02)^{\star \star *}\end{array}$ & $\begin{array}{l}-0,042 \\
(0,58)\end{array}$ & $\begin{array}{l}-0,068 \\
(0,96)\end{array}$ & $\begin{array}{r}0,137 \\
(0,95)\end{array}$ & $\begin{array}{c}0,213 \\
(1,42)\end{array}$ \\
\hline Lag Revenue Level & $\begin{array}{l}0,350 \\
(4,26)^{\star \star *}\end{array}$ & $\begin{array}{l}0,396 \\
(4,48)^{\star * *}\end{array}$ & $\begin{array}{c}0,039 \\
(2,36)^{\star *}\end{array}$ & $\begin{array}{c}0,032 \\
(1,92)^{*}\end{array}$ & $\begin{array}{l}0,018 \\
(2,96)^{\star \star *}\end{array}$ & $\begin{array}{c}0,014 \\
(2,09)^{* *}\end{array}$ & $\begin{array}{l}0,075 \\
(3,04)^{\star \star * *}\end{array}$ & $\begin{array}{l}0,101 \\
(3,45)^{\star \star *}\end{array}$ \\
\hline Revenue Change & $\begin{array}{l}0,613 \\
(2,22)^{\star *}\end{array}$ & $\begin{array}{l}0,595 \\
(2,13)^{\star \star}\end{array}$ & $\begin{array}{l}-0,005 \\
(0,11)\end{array}$ & $\begin{array}{l}-0,044 \\
(0,96)\end{array}$ & $\begin{array}{r}0,058 \\
(1,82)^{*}\end{array}$ & $\begin{array}{l}0,045 \\
(1,46)\end{array}$ & $\begin{array}{l}-0,063 \\
(0,71)\end{array}$ & $\begin{array}{l}-0,066 \\
(0,69)\end{array}$ \\
\hline $\begin{array}{l}\text { Lag Low Dem* } \\
\text { Change Rev }\end{array}$ & $\begin{array}{l}-0,033 \\
(0,10)\end{array}$ & $\begin{array}{l}-0,000 \\
(0,00)\end{array}$ & $\begin{array}{r}0,074 \\
(1,51)\end{array}$ & $\begin{array}{l}0,115 \\
(2,15)^{\star *}\end{array}$ & $\begin{array}{l}-0,006 \\
(0,15)\end{array}$ & $\begin{array}{c}0,008 \\
(0,22)\end{array}$ & $\begin{array}{r}0,161 \\
(1,58)\end{array}$ & $\begin{array}{r}0,150 \\
(1,42)\end{array}$ \\
\hline $\begin{array}{l}\text { Lag High Dem* } \\
\text { Change Rev }\end{array}$ & $\begin{array}{l}-0,298 \\
(1,02)\end{array}$ & $\begin{array}{l}-0,263 \\
(0,88)\end{array}$ & $\begin{array}{r}0,057 \\
(1,06)\end{array}$ & $\begin{array}{c}0,096 \\
(1,72)^{*}\end{array}$ & $\begin{array}{l}-0,022 \\
(0,64)\end{array}$ & $\begin{array}{l}-0,011 \\
(0,32)\end{array}$ & $\begin{array}{r}0,157 \\
(1,64)\end{array}$ & $\begin{array}{r}0,169 \\
(1,65)^{\star}\end{array}$ \\
\hline Constant & $\begin{array}{l}0,382 \\
(0,04)\end{array}$ & $\begin{array}{l}0,323 \\
(0,04)\end{array}$ & $\begin{array}{l}-2,327 \\
(1,51)\end{array}$ & $\begin{array}{l}-0,779 \\
(0,52)\end{array}$ & $\begin{array}{l}2,103 \\
(1,43)\end{array}$ & $\begin{array}{l}0,942 \\
(0,63)\end{array}$ & $\begin{array}{l}-0,665 \\
(0,21)\end{array}$ & $\begin{array}{l}-2,268 \\
(0,71)\end{array}$ \\
\hline Low Dem Cond, Effect & $0,58^{* * *}$ & $0,59^{* * *}$ & $0,07^{* * *}$ & $0,07^{* *}$ & $0,05^{* *}$ & $0,05^{* *}$ & $0,10^{* *}$ & $0,08^{* *}$ \\
\hline High Dem Cond, Effect & $0,31^{* * *}$ & $0,33^{* * *}$ & 0,05 & 0,05 & $0,04^{* *}$ & $0,03^{* *}$ & $0,09^{* * *}$ & $0,10^{* * *}$ \\
\hline $\begin{array}{l}\mathrm{P} \text { (Cond Effect } \neq \\
\text { Interactive) }\end{array}$ & $0,04^{* *}$ & $0,05^{* *}$ & 0,90 & 0,41 & $0,07^{*}$ & 0,22 & 0,48 & 0,50 \\
\hline Observations & 238 & 218 & 131 & 125 & 174 & 168 & 170 & 164 \\
\hline R-Squared & 0,25 & 0,26 & 0,24 & 0,26 & 0,17 & 0,20 & 0,25 & 0,22 \\
\hline
\end{tabular}

* Significant at $10 \% ;{ }^{* *}$ significant at $5 \% ;{ }^{* * *}$ significant at $1 \%$ 
TABLE 11: Interaction of Revenue Change and Regime Type in East Asia (PCSE MODEL)

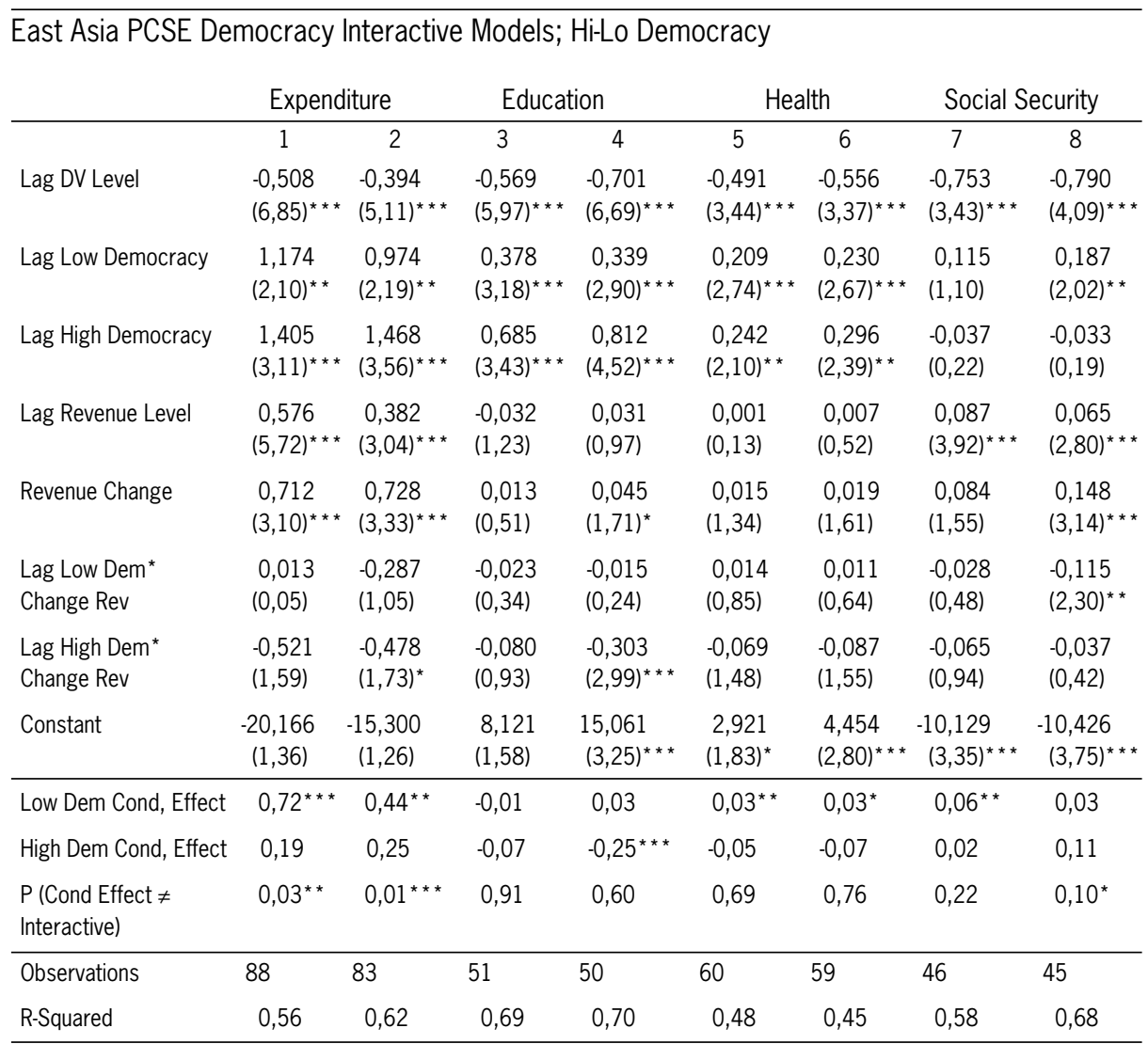

* Significant at $10 \% ;{ }^{* *}$ significant at $5 \% ;{ }^{* *}$ significant at $1 \%$ 
TABLE 12: Interaction of Revenue Change and Regime Type in Post-Socialist Countries (PCSE MODEL)

\begin{tabular}{|c|c|c|c|c|c|c|c|c|}
\hline \multicolumn{9}{|c|}{ Eastern Europe PCSE Democracy Interactive Models; Hi-Lo Democracy } \\
\hline & \multicolumn{2}{|c|}{ Expenditure } & \multicolumn{2}{|c|}{ Education } & \multicolumn{2}{|c|}{ Health } & \multicolumn{2}{|c|}{ Social Security } \\
\hline & 1 & 2 & 3 & 4 & 5 & 6 & 7 & 8 \\
\hline Lag DV Level & $\begin{array}{l}-0,541 \\
(4,81)^{\star \star *}\end{array}$ & $\begin{array}{l}-0,520 \\
(4,25)^{\star \star *}\end{array}$ & $\begin{array}{l}-0,381 \\
(3,83)^{\star * *}\end{array}$ & $\begin{array}{l}-0,264 \\
(2,43)^{\star *}\end{array}$ & $\begin{array}{l}-0,279 \\
(3,10)^{\star * *}\end{array}$ & $\begin{array}{l}-0,233 \\
(2,45)^{\star \star}\end{array}$ & $\begin{array}{l}-0,279 \\
(3,10)^{\text {*** }}\end{array}$ & $\begin{array}{l}-0,233 \\
(2,45)^{\star *}\end{array}$ \\
\hline Lag Low Democracy & $\begin{array}{l}-0,216 \\
(0,34)\end{array}$ & $\begin{array}{l}-0,258 \\
(0,33)\end{array}$ & $\begin{array}{l}0,629 \\
(2,67)^{\star \star *}\end{array}$ & $\begin{array}{c}0,269 \\
(1,16)\end{array}$ & $\begin{array}{l}-1,124 \\
(2,22)^{\star \star}\end{array}$ & $\begin{array}{l}-1,295 \\
(2,52)^{\star *}\end{array}$ & $\begin{array}{l}-1,124 \\
(2,22)^{\star *}\end{array}$ & $\begin{array}{l}-1,295 \\
(2,52)^{\star *}\end{array}$ \\
\hline Lag $\mathrm{Hi}$ & $\begin{array}{c}1,253 \\
(1,72)^{\star}\end{array}$ & $\begin{array}{l}2,756 \\
(2,63)^{\star * *}\end{array}$ & $\begin{array}{c}0,867 \\
(3,13)^{\star * *}\end{array}$ & $\begin{array}{c}0,464 \\
(1,81)^{*}\end{array}$ & $\begin{array}{l}0,389 \\
(0,79)\end{array}$ & $\begin{array}{c}0,516 \\
(1,22)\end{array}$ & $\begin{array}{l}0,389 \\
(0,79)\end{array}$ & $\begin{array}{l}0,516 \\
(1,22)\end{array}$ \\
\hline Lag Revenue Level & $\begin{array}{l}0,600 \\
(5,69)^{\star \star * *}\end{array}$ & $\begin{array}{l}0,576 \\
(3,39)^{\star \star * *}\end{array}$ & $\begin{array}{c}0,014 \\
(0,48)\end{array}$ & $\begin{array}{l}-0,016 \\
(0,61)\end{array}$ & $\begin{array}{l}0,054 \\
(0,78)\end{array}$ & $\begin{array}{c}0,039 \\
(0,47)\end{array}$ & $\begin{array}{l}0,054 \\
(0,78)\end{array}$ & $\begin{array}{c}0,039 \\
(0,47)\end{array}$ \\
\hline Revenue Change & $\begin{array}{l}0,952 \\
(5,09)^{\star \star *}\end{array}$ & $\begin{array}{l}1,242 \\
(6,48)^{\star \star *}\end{array}$ & $\begin{array}{l}0,398 \\
(4,73)^{\star \star *}\end{array}$ & $\begin{array}{l}0,327 \\
(4,16)^{\star \star \star}\end{array}$ & $\begin{array}{l}-0,368 \\
(2,03)^{\star \star}\end{array}$ & $\begin{array}{l}-0,207 \\
(1,10)\end{array}$ & $\begin{array}{l}-0,368 \\
(2,03)^{\star \star}\end{array}$ & $\begin{array}{l}-0,207 \\
(1,10)\end{array}$ \\
\hline $\begin{array}{l}\text { Lag Low Dem* } \\
\text { Change Rev }\end{array}$ & $\begin{array}{l}-0,247 \\
(1,02)\end{array}$ & $\begin{array}{l}-0,505 \\
(1,73)^{*}\end{array}$ & $\begin{array}{l}-0,278 \\
(3,05)^{\star \star *}\end{array}$ & $\begin{array}{l}-0,245 \\
(2,47)^{\star *}\end{array}$ & $\begin{array}{r}0,386 \\
(1,89)^{*}\end{array}$ & $\begin{array}{l}0,085 \\
(0,36)\end{array}$ & $\begin{array}{r}0,386 \\
(1,89)^{*}\end{array}$ & $\begin{array}{c}0,085 \\
(0,36)\end{array}$ \\
\hline $\begin{array}{l}\text { Lag High Dem* } \\
\text { Change Rev }\end{array}$ & $\begin{array}{r}0,110 \\
(0,40)\end{array}$ & $\begin{array}{l}-0,270 \\
(0,78)\end{array}$ & $\begin{array}{l}-0,324 \\
(3,67)^{\star * *}\end{array}$ & $\begin{array}{l}-0,288 \\
(3,13)^{\star \star *}\end{array}$ & $\begin{array}{l}0,388 \\
(1,78)^{*}\end{array}$ & $\begin{array}{l}0,255 \\
(1,08)\end{array}$ & $\begin{array}{c}0,388 \\
(1,78)^{*}\end{array}$ & $\begin{array}{r}0,255 \\
(1,08)\end{array}$ \\
\hline Constant & $\begin{array}{l}25,272 \\
(1,71)^{*}\end{array}$ & $\begin{array}{l}17,445 \\
(0,94)\end{array}$ & $\begin{array}{l}17,539 \\
(2,14)^{\star *}\end{array}$ & $\begin{array}{l}21,620 \\
(2,30)^{* *}\end{array}$ & $\begin{array}{c}12,984 \\
(1,20)\end{array}$ & $\begin{array}{c}16,479 \\
(1,45)\end{array}$ & $\begin{array}{c}12,984 \\
(1,20)\end{array}$ & $\begin{array}{l}16,479 \\
(1,45)\end{array}$ \\
\hline Low Dem Cond, Effect & $0,71^{* * *}$ & $0,74^{\star * *}$ & $-0,05$ & 0,04 & $0,12^{* *}$ & 0,09 & 0,02 & $-0,12$ \\
\hline High Dem Cond, Effect & $1,06^{* * *}$ & $0,97^{\star * *}$ & $-0,01$ & $-0,01$ & $0,07^{*}$ & 0,04 & 0,02 & 0,05 \\
\hline $\begin{array}{l}\mathrm{P}(\text { Cond Effect } \neq \\
\text { Interactive) }\end{array}$ & $0,01^{* * *}$ & $0,01^{* \star *}$ & $0,05^{* *}$ & $0,01^{* * *}$ & $0,01^{* * *}$ & $0,01^{* * *}$ & $0,10^{*}$ & 0,38 \\
\hline Observations & 95 & 63 & 50 & 45 & 50 & 45 & 95 & 63 \\
\hline R-Squared & 0,62 & 0,68 & 0,76 & 0,76 & 0,57 & 0,54 & 0,42 & 0,41 \\
\hline
\end{tabular}

* Significant at $10 \% ;{ }^{* *}$ significant at $5 \% ;{ }^{* * *}$ significant at $1 \%$ 


\section{CONCLUSION}

The two decades from 1980-2000 were a period of substantial economic and political change for the countries in Latin America, East Asia and Central Europe. In this paper, we attempt a preliminary assessment of the consequences of these changes for social spending in the three regions. Our central theoretical intuition was that it is important to take historical legacies into account, including prior social commitments and past patterns of social spending.

In this respect, we observed considerable evidence of differences across the regions. Descriptive statistics show that despite a sharp decline in aggregate central government expenditures, the post-socialist countries of Eastern Europe continued to spend substantially more than their Latin American counterparts in the three social categories. This, as we suggested, reflected a legacy of strong, generalized expectations about entitlements to social protection and services.

Cross-sectional and time-series analysis showed that long-run revenue constraints were important in all three regions, but that the effects of short-run changes in revenue were most consistently negative in Latin America. We suggested that one reason for this vulnerability might be the longstanding mismatch between the tax base and the extent of social commitments. By contrast, we found that democracy appeared to have some effect on social spending in Asia, which might be attributed to the generally stronger fiscal position those countries enjoyed going into the transition process (Haggard and Kaufman, 1995). With respect to the post-socialist countries, effects were generally more mixed. Although the region also witnessed strong pressures to rationalize social policy, the universal character of coverage limited the capacity of new democratic governments to dismantle existing protections.

Responses to trade openness also varied, although the results appear less striking than what other studies have suggested. Latin American countries tended to reduce social security spending as they became more exposed to trade. The effects of greater trade openness on post-socialist countries may also have been negative, although coefficients did not reach standards levels of significance. Conversely, trade openness appeared to increase social security spending in East Asia. Over the longer-run we also noted a positive relationship between trade openness and spending on both health and education, but these effects did not appear to operate consistently in the shortrun within any of the three regions.

Caution with respect to these findings is warranted in at least two respects. First, there are empirical limitations that are standard in statistical studies of this sort. Our findings on revenues were highly robust, and the regional differences in democracy held for a variety of different specifications of the model. Results for trade openness, however, were less stable, suggesting that the effects may be more modest than has sometime been thought. More surprising, we did not find that the tremendous volatility of capital flows appeared to affect spending significantly either, at least when expressed a share of GDP. These findings, of course, may reflect substantive realities, but may also be the product of unreliable data.

A second set of issues is theoretical. Although it is plausible that the cross-regional differences we have observed rest on a reasonably sound empirical foundation, the causal mechanisms that account for these differences remain to be explored. As we have argued, they are consistent with 
our theoretical hunches with respect to the effects of welfare legacies and "soft" path-dependent constraints. But such hunches need to be explored systematically against the causal influence of concurrent political and economic pressures.

Our findings with respect to the importance of fiscal constraints have implications that extend beyond the issue of social spending per se. Fiscal constraints not only affect spending, they can have important effects on the broader agenda of policy reform as well. In fiscally-constrained countries, the relative efficiency of social policy becomes an especially salient issue in reform debates. In both Latin America and Central Europe, the issue of "affordability" casts an ongoing shadow over the policy debate and often dominates reforms that seek to expand coverage, services, and the protections of the welfare system. Such issues weighed much less heavily during the 1990s in most East Asian countries.

Although a variety of other factors influence the way such issues are resolved, fiscal constraints also have an important effect on the politics of social policy. Fiscal constraints have contributed in many instances to the empowerment of "technocratic" actors inclined to shift greater responsibility for insurance and services onto individuals and the private sector. Conversely, they tend to weaken parties, unions, and other organizations that are more conventionally oriented toward egalitarian goals. While such organizations may still have room for maneuver within a system with high fiscal constraints, the costs of ignoring these constraints are high. As a consequence, the partisan differences between "left" and "right" are likely to be narrower than they would be in a more permissive fiscal environment

\section{REFERENCES}

Arreaza, Adriana, Bent Sorenson and Oved Yosha. 1999. "Consumption Smoothing through Fiscal Policy in OECD and EU Countries." In Fiscal Institutions and Fiscal Performance, edited by James Poterba and Jurgen von Hagen. Chicago: The University of Chicago Press, 59-80.

Avelino, George, David Brown and Wendy Hunter. 2003. "The Effects of Capital Mobility, Trade Openness, and Democracy on Social Spending in Latin America, 1980-1999", unpublished ms.

Baum, Matthew and David Lake. 2001. "The Invisible Hand of Democracy: Political Control and the Provision of Public Services." Comparative Political Studies 34 (6): 587-621.

Beck, Neal and Jonathan N. Katz. 1995. "What to Do (and Not to Do) with Time-Series-Cross-Section Data." American Political Science Review 89 (3): 634-647.

Beck, Neal and Jonathan N. Katz. 1996. "Nuisance vs. Substance: Specifying and Estimating Time-Series-Cross-Section Models." Political Analysis 6: 1-36.

Boix, Carles. 1998. Political Parties, Growth and Equality: Conservative and Social Democratic Economic Strategies in the World Economy. New York: Cambridge University Press.

Brown, David and Wendy Hunter. 1999. "Democracy and Social Spending in Latin America, 1980-92." American Political Science Review 93 (4): 779-90

Burgoon, Brian. 2001. "Globalization and Welfare Compensation: Disentangling the Ties that Bind." International Organization 55 (3): 509-51.

Cameron, David. 1978. "The Expansion of the Public Sector: A Comparative Analysis." American Political Science Review 72 (4): $1243-61$.

Chaudhry, Kiren. 1997. The Price of Wealth: Economics and Institutions in the Middle East. Ithaca: Cornell University Press.

Cheibub, Jose. 1998. "Political Regimes and the Extractive Capacity of Governments: Taxation in Democracies and Dictatorships." World Politics 50 (3): 349-376. 
Esping-Andersen, Gosta. 1990. The Three World of Welfare Capitalism. Cambridge: Polity.

Frey, R. Scott and Ali Al-Roumi. 1999. "Political Democracy and the Physical Quality of Life: the Cross-National Evidence." Social Indicators Research 47 (1):73-97.

Frye, Tim. 2003. "State Spending and Globalization in the Post-Communist World", unpublished ms.

Garrett, Geoffrey. 1998. Partisan Politics in the Global Economy. Cambridge: Cambridge University Press.

Garrett, Geoffrey. 2000. "Globalization and Government Spending Around the World." Studies in Comparative International Development 35 (4): 3-29.

Garrett, Geoffrey. 2001. "The Distributive Consequences of Globalization”, unpublished ms., Yale University.

Garrett, Geoffrey and Deborah Mitchell. 2001. "Globalization, Government Spending and Taxation in the OECD." European Journal of Political Research 39(2): 145-177.

Garrett, Geoffrey and David Nickerson. 2001. "Democratization and Government Spending in Middle-Income Countries." In Globalization, unpublished ms..Yale University.

Gilbert, Neil. 2002. Transformation of the Welfare State: the Silent Surrender of Public Responsibility. New York: Oxford University Press.

Grunberg, Isabelle. 1998. "Double Jeopardy: Globalization, Liberalization and the Fiscal Squeeze." World Development 26 (4): 591-605.

Hall, Peter A. and David Soskice (eds). 2001. Varieties of Capitalism: The Institutional Foundations of Comparative Advantage. New York: Oxford.

Haggard, Stephan. 1990. Pathways from the Periphery: the Politics of Growth in the Newly Industrializing Countries. Ithaca: Cornell University Press.

Haggard, Stephan and Robert Kaufman. 1995. The Political Economy of Democratic Transitions. Princeton: Princeton University Press.

Hallerberg, Mark and Rolf Strauch. 2002. "On the Cyclicality of Public Finances in Europe." Empirica 29: 183-207.

Huber, Evelyne. 2002. Models of Capitalism: Lessons for Latin America. University Park: Penn State Press.

Iverson, Torben. 2001. "The Dynamics of Welfare State Expansion: Trade Openness, De-Industrialization, and Partisan Politics." In The New Politics of the Welfare State, edited by Paul Pierson. New York: Oxford University Press, 45-80.

Kapstein, Ethan and Branko Milanovic. 2003. Income and Influence: Social Policy in Emerging Market Economies. Kalamazoo: W.E. Upjohn Institute.

Kato, Junko. 2002. Regressive Taxation and the Welfare State: Path Dependence and Policy Diffusion. New York: Cambridge University Press.

Katzenstein, Peter. 1985. Small States in World Markets. Ithaca: Cornell University Press.

Kaufman, Robert and Alex Segura-Ubiergo. 2001. "Globalization, Domestic Politics and Welfare Spending in Latin America: A Time-Series Cross-Section Analysis, 1973-1997." World Politics 53 (4): 553-87.

Lipsmeyer, Christine S. 2002. "Parties and Policy: Evaluating Economic and Partisan Influences on Welfare Policy Spending during the European Post-Communist Transition." British Journal of Political Science 32 (4): 641-661.

Mahoney, James and Dietrich Rueschemeyer. 2002. Comparative Historical Analysis in the Social Sciences. New York: Cambridge University Press.

Mares, Isabella. 2003. "Social Protection around the World: External Insecurity, State Capacity, and Domestic Political Cleavages", unpublished ms.. Stanford University.

McGuire, James. 2001. "Social Policy and Mortality Decline in East Asia and Latin America." World Development 29 (10): $1673-$ 1697.

Moore, Mick. 1998. "Death Without Taxes." In The Democratic Developmental State, edited by Robinson and White. Oxford: Oxford University Press, 84-124.

Pierson, Paul. 1994. Dismantling the Welfare State? Reagan, Thatcher and the Politics of Retrenchment. New York: Cambridge University Press.

Rajkumar, Andrew Sunil and Vinaya Swaroop. 2002. "Public Spending and Outcomes: Does Governance Matter?", unpublished ms., The World Bank. 
Remmer, Karen. 2004. "Does Foreign Aid Promote the Expansion of Government?" American Journal of Political Science 48 (1): 76-91.

Rodrik, Dani. 1997. Has Globalization Gone Too Far? Washington DC: Institute for International Economics.

Rodrik, Dani. 1998. "Why Do More Open Economies Have Bigger Governments?” Journal of Political Economy 106 (5): 997-1033.

Rodrik, Dani 1999. The New Global Economy and Developing Countries: Making Openness Work. Washington D.C.: Overseas Development Council Policy Essay \#24.

Rudra, Nita. 2002. "Globalization and the Decline of the Welfare State in Less Developed Countries." International Organization 56 (2): 411-455.

Stephens, John D. Evelyne Huber and Leonard Ray. 1999. "The Welfare State in Hard Times." In Continuity and Change in Contemporary Capitalism, edited by Herbert Kitschelt, Peter Lange, Gary Marks and John D. Stephens. New York: Cambridge University Press, 164-194.

Swank, Duane. 1998. "Funding the Welfare State: Globalization and the Taxation of Business in Advanced Market Economies." Political Studies 46 (4): 671-92.

Swank, Duane. 2001. "Political Institutions and Welfare State Restructuring: the Impact of Institutions on Social Policy Change in Developed Democracies." In The New Politics of the Welfare State, edited by Paul Pierson. New York: Oxford University Press, 197-238.

Wibbels, Erik. 2003. "Global Imperatives and Domestic Priorities: Internationalization, Business Cycles, and Social Spending in Latin America", unpublished ms.. University of Washington.

Stephan Haggard is the Lawrence and Sallye Krause Professor at the Graduate School of International Relations and Pacific Studies, University of California, San Diego. He is the author of Pathways from the Periphery (1990), The Political Economy of Democratic Transitions (1995, with Robert Kaufman), The Political Economy of the Asian Financial Crisis (2000) and From Silicon Valley to Singapore: Location and Competitive Advantage in the Hard Disk Drive Industry (2000 with David McKendrick and Richard Doner).

(E-Mail: shaggard@ucsd.edu)

Robert R. Kaufman is Professor of Political Science at Rutgers University. Recent publications include Urgent Needs, Weak Incentives: The Politics of Health and Education Reform in Latin America (2004, with Joan M. Nelson), "Globalization, Domestic Politics, and Social Spending in Latin America 1973-1997: A Cross-Sectional Time Series Analysis." (2001 with Alex Segura-Ubiergo), and Reforming the State: Fiscal and Welfare Reform in Transition Economies (2000 with Janos Kornai and Stephan Haggard).

(E-Mail: kaufrutger@aol.com) 